\title{
The Corporate Shareholder's Vote and its Political Economy, in Delaware and in Washington
}

\section{Citation}

Mark J. Roe, The Corporate Shareholder's Vote and its Political Economy, in Delaware and in Washington, 2 Harv. Bus. L. Rev. 1 (2012).

\section{Published Version}

http://www.hblr.org/wp-content/uploads/2012/07/HLB204.pdf

\section{Permanent link}

http://nrs.harvard.edu/urn-3:HUL.InstRepos:30011106

\section{Terms of Use}

This article was downloaded from Harvard University's DASH repository, and is made available under the terms and conditions applicable to Open Access Policy Articles, as set forth at http:// nrs.harvard.edu/urn-3:HUL.InstRepos:dash.current.terms-of-use\#OAP

\section{Share Your Story}

The Harvard community has made this article openly available.

Please share how this access benefits you. Submit a story.

Accessibility 
ISSN 1936-5349 (print)

ISSN 1936-5357 (online)

\title{
HARVARD
}

JOHN M. OLIN CENTER FOR LAW, ECONOMICS, AND BUSINESS

\section{THE CORPORATE SHAREHOLDER'S VOTE AND ITS POLITICAL ECONOMY, IN DELAWARE AND IN WASHINGTON}

\author{
Mark J. Roe
}

Discussion Paper No. 738

$10 / 2012$

Harvard Law School

Cambridge, MA 02138

This paper can be downloaded without charge from:

The Harvard John M. Olin Discussion Paper Series: http://www.law.harvard.edu/programs/olin_center/

This paper is also a discussion paper of the John M. Olin Center’s Program on Corporate Governance. 


\title{
The Corporate Shareholder's Vote and Its Political Economy, in Delaware and in Washington
}

\begin{abstract}
Mark J. Roe
Abstract

Shareholder power to effectively nominate, contest, and elect the company's board of directors became core to the corporate governance reform agenda in the past decade, as corporate scandal and financial stress put business failures and scandals into headlines and onto policymakers' agendas. As is well known to corporate analysts, the incentive structure in corporate elections typically keeps shareholders passive, and incumbent boards largely control the electoral process, usually nominating and electing themselves or their chosen successors. Contested corporate elections are exceedingly rare. But shareholder power to directly place their nomination for a majority of the board in the company-paid-for voting documents, as the SEC has pushed toward, could revolutionize American corporate governance by sharply shifting authority away from insiders, boards, and corporate managements. During the past decade, the SEC proposed, withdrew, and then promulgated rules that would shift the control of some corporate election machinery, to elect a minority of the board, away from insiders and into shareholders' hands. Then, in July 2011, the D.C. Circuit Court of Appeals struck down the most aggressive of the SEC's rules.

During this decade-long process a core corporate law was up for grabs, but the action was in Washington, not the states, until the end of the decade, despite that a century of corporate law theory has focused on jurisdictional competition among states in making corporate law. In earlier work, I amended the state competition understanding with a view that key features of American corporate lawmaking are Washington-oriented: Washington often makes corporate law directly, it did so for the central corporate controversy in most decades of the twentieth century, and it can influence state lawmaking, either directly or by establishing complements and substitutes to state corporate law. Shareholder access fits this federal-state paradigm and goes beyond it. It fits in that states were largely silent on these shareholder-power initiatives until 2009, when Delaware amended its corporate code to facilitate shareholder nominees. Indeed, it's hard to understand Delaware passing its 2009 shareholder statute if the issue had not been on the national agenda for nearly a decade. But the interaction goes beyond a basic Washington-Delaware paradigm in that Delaware's corporate lawmaking could have influenced the federal outcome and, quite plausibly, corporate players sought it, or used it, as a tool to dampen federal congressional, judicial, and regulatory actors' enthusiasm for strong shareholder access. The federal-state interaction is two-way. The analytic potential for a strategic, two-way interaction is enhanced because the strongest interest group inputs at each jurisdictional level sharply differ. Overall, the vertical interaction between states and Washington in reforming shareholder-insider voting power in the past decade is a far cry from the classical understanding of American corporate law being honed in horizontal state-to-state competition, and it implicates sharply differing political economy, interest-group dynamics.
\end{abstract}




\title{
The Corporate Shareholder's Vote and Its Political Economy, in Delaware and in Washington
}

\author{
Mark J. Roe
}

Table of Contents

Introduction

I. The Classical View of American Corporate Lawmaking

II. The SEC Post-2000 Action to Reshape Power Inside the Large American Firm..................................

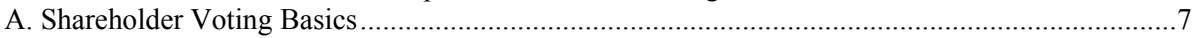

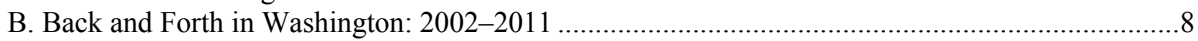

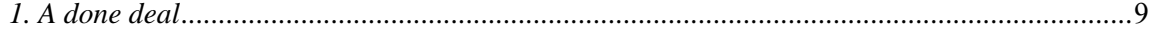

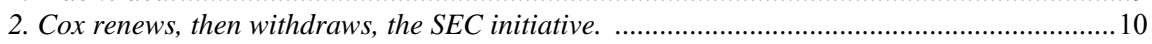

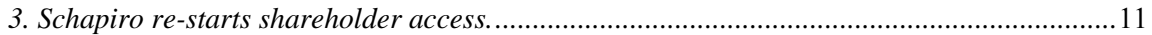

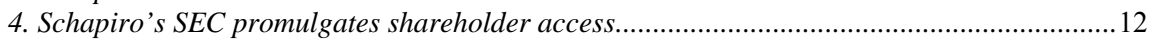

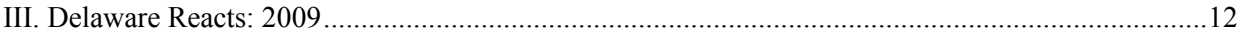

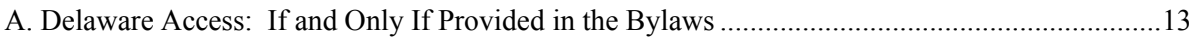

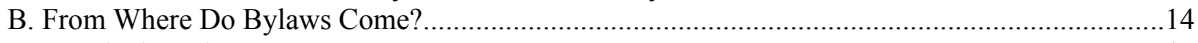

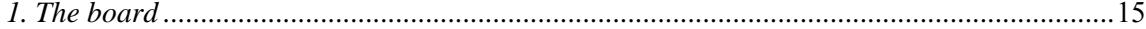

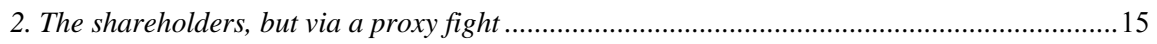

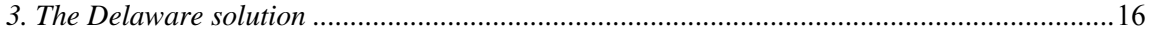

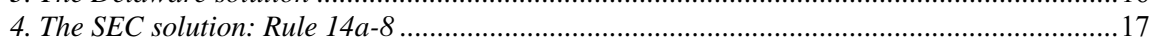

IV. Concrete Public Choice, Federal-State Explanations .......................................................................17

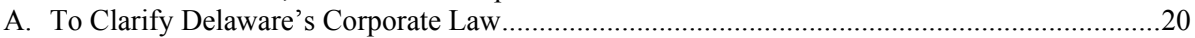

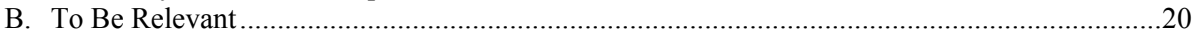

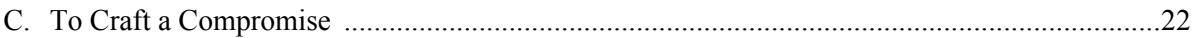

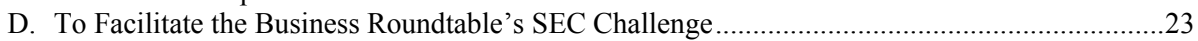

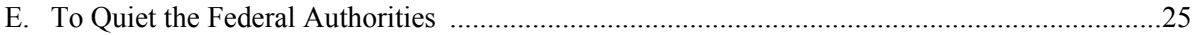

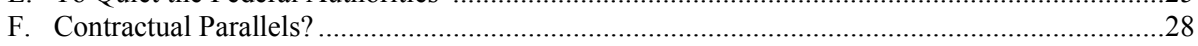

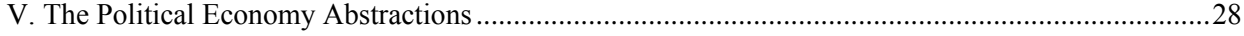

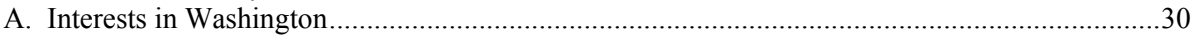

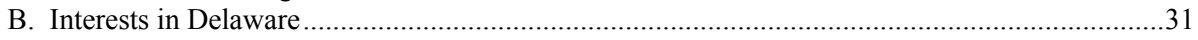

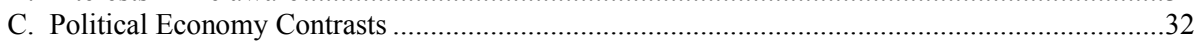

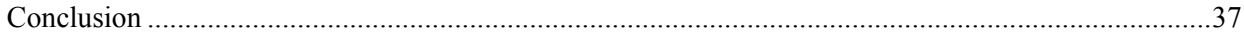

Figure 1. Activism of the influential shareholder: Reducing vertical agency costs vs. raising horizontal influence costs

Figure 2. Costs and coalitions: The financial shareholder as swing player in access .................................. 


\title{
The Corporate Shareholder's Vote and Its Political Economy, in Delaware and in Washington
}

\author{
Mark J. Roe ${ }^{*}$
}

\section{INTRODUCTION}

In the past decade, the Securities and Exchange Commission proposed, withdrew, proposed again, amended, and then last year promulgated rules to shift power in the large American public corporation from insiders, managers, and boards of directors to outside shareholders. ${ }^{1}$ Doubts existed initially as to whether the SEC had authority to issue such rules, and Congress in 2010, while passing the Dodd-Frank financial reform act, explicitly conferred the SEC with authority to issue such rules. ${ }^{2}$ The SEC quickly used that authority, promulgating such rules in August 2010. Business interests immediately challenged the SEC rule-making and, in July 2011, the District of Columbia Circuit Court of Appeals struck down the most aggressive of the SEC rules. ${ }^{3}$ These rules were central to corporate reformers' agenda, and the reformers were deeply disappointed when the D.C. Circuit struck them down. ${ }^{4}$

This process for corporate lawmaking would have surprised the late twentieth century reader of prominent law reviews' analytics of the corporate lawmaking process, which has long been thought to be state-based, with state competition for corporate chartering revenue seen to be a major factor driving what rules arise and survive. Yet for the past decade the major corporate law reform initiative was debated primarily at the federal and not the state level. Only at the end of the decade did the nearly exclusively federal arena open up, when the major corporate-chartering state, Delaware, amended its statutory

* Professor of Law, Harvard Law School. Thanks for comments on a prior draft go to Michal Barzuza, John Coffee, Charles Elson, Luca Enriques, Jeffrey Gordon, Joseph Grundfest, Larry Hamermesch, Gerard Hertig, Kate Judd, Marcel Kahan, Brett McDonnell, Curtis Milhaupt, Holger Spamann, Guhan Subramanian, and participants in workshops at the law schools at Bocconi, Columbia and Virginia.

${ }^{1}$ Facilitating Shareholder Director Nominations Final Rule, 75 Fed. Reg. 56,668 (Sept. 16, 2010).

${ }^{2}$ Dodd-Frank Wall Street Reform and Consumer Protection Act, Pub. L. No. 111-203, § 971, 124 Stat. $1376(2010)$.

${ }^{3}$ Bus. Roundtable and Chamber of Commerce of U.S. v. SEC, 647 F.3d 1144 (D.C. Cir. 2011).

${ }^{4}$ See Jessica Holzer, Court Deals Blow to SEC, Activists, WALL ST. J., July 23-24, 2011, at B3; Edward Wyatt, Appeals Court Rejects S.E.C. Rule on Access to Proxy Materials, N.Y. TimES, July 23, 2011, at B3. 
voting rules in the wake of the federal ship's movements. Classic state competition does not seem to have been in play. Instead of the jurisdictional interaction being between states, the interplay was between the major corporate chartering state and Washington. As such, the inputs, mechanisms, and interests behind corporate lawmaking in the United States need to be reexamined in light of the past decade's corporate law action, as I do here.

Understanding the structural dynamics of state-based corporate lawmaking has been a long-standing task for corporate law academics. Central to the original thinking was that states compete for corporate chartering revenues, with each state selling charters to firms, for the fees that would enrich that state's treasury. Indeed, up to a quarter of Delaware's budget comes each year from chartering revenues. ${ }^{5}$ Some analysts saw the competitive race as one to the top ${ }^{6}$ - making for more efficient corporate law; others saw it as one to the bottom-as pandering states made an insider-friendly corporate law. ${ }^{7}$ The horizontal, state-to-state competition literature is substantial, deep, and insightful, having engaged some of best minds in corporate law analysis. ${ }^{8}$

Those older modes of analysis do not work for the past decade of shareholder voting reform. The shareholder voting action is more consistent with newer, disruptive views that state-to-state competition is weak (with Delaware having a monopoly) ${ }^{9}$ and that much de facto corporate lawmaking is done in Washington, not Delaware, and that this has been so for quite some

5 See Delaware Dep't of State, Div. of Corp., Annual Report (2009), available at http://corp.delaware.gov/2009ar.pdf.

${ }^{6}$ See Ralph K. Winter, Jr., State Law, Shareholder Protection, and the Theory of the Corporation, 6 J. LEGAL STUD. 251, 256, 290 (1977).

${ }^{7}$ See William L. Cary, Federalism and Corporate Law: Reflections upon Delaware, 83 YALE L.J. 663, 701 (1974).

${ }^{8}$ For further major race-to-the-top views, see RoBERTA ROMANO, THE GENIUS OF AMERICAN CORPORATE LAW (1993); William J. Carney, The Political Economy of Competition for Corporate Charters, 26 J. Legal STUD. 303 (1997); Robert Daines, Does Delaware Law Improve Firm Value?, 62 J. FIN. ECON. 525 (2001); Daniel R. Fischel, The "Race to the Bottom" Revisited: Reflections on Recent Developments in Delaware's Corporation Law, 76 Nw. U. L. REV. 913 (1982); Ralph K. Winter, The "Race for the Top" Revisited: A Comment on Eisenberg, 89 COLUM. L. REV. 1526 (1989).

For further race-to-the-bottom views, see Louis K. Liggett Co. v. Lee, 288 U.S. 517, 54865 (1933) (Brandeis, J., dissenting in part); Lucian Arye Bebchuk, Federalism and the Corporation: The Desirable Limits on State Competition in Corporate Law, 105 HARV. L. REV. 1435 (1992); Melvin Aron Eisenberg, The Structure of Corporation Law, 89 COLUM. L. REV. 1461 (1989); Guhan Subramanian, The Disappearing Delaware Effect, 20 J.L. ECON. \& ORG. 32 (2004).

${ }^{9}$ See Marcel Kahan \& Ehud Kamar, The Myth of State Competition in Corporate Law, 55 STAN. L. REV. 679 (2002). 
time. ${ }^{10}$ The past decade's action on shareholder voting fits well with the view that Delaware's corporate lawmaking does not face stiff state competition and fits even better with the new focus on Delaware-Washington interaction. But the interaction goes beyond prior analytics in that one can see Delaware not just following in the federal wake, but positioning itself to influence the tenor of the federal outcome. The Washington-Delaware interaction is two-way.

These considerations have political economy dimensions as well, with one dimension of the federal-state interaction is easy to discern, while the other, more important one is not. The easy-to-see feature is that the state rulemaking emerged after nearly a decade of federal consideration of changing the shareholder voting rules. It seems plausible, even obvious, that the major incorporating state enacted its shareholder-oriented statute because insistent federal action induced state-based corporate players to put the rule on the state's agenda. Less obvious but more important is how interest groups' stakes in the outcome affected the nature, scope, interaction, and tenor of the rules at each jurisdictional level.

Once one abandons the old, once dominant state competition framework - or at least looks beyond it - to analyze the corporate voting laws of the past decade, a dynamic political economy structure emerges. The politically influential groups for corporate lawmaking are not identical in Delaware and in Washington. Indeed, they often are at odds with one another inside the large corporation and at odds with one another in the polity generally. This political economy dynamic deserves analysis and gets it here.

The analytic focus for the new shareholder voting mechanism has thus far largely been on whether it will enhance or degrade corporate governance, and what form it should take. Should it be permissive or mandatory? What shape should the statutory default rules take? Who should have access to companypaid voting machinery, and when? ${ }^{11}$ But to understand the law that emerges, the political economy of corporate lawmaking also needs attention. ${ }^{12}$ Delaware's

${ }^{10}$ See Mark J. Roe, Delaware's Competition, 117 HARV. L. REV. 588, 590 (2003); Mark J. Roe, Regulatory Competition in Making Corporate Law in the United States-And Its Limits, 21 OXford ReV. ECON. POliCy 232 (2005); Mark J. Roe, Washington and Delaware in American Corporate Lawmaking, 34 DEL. J. CORP. L. 1 (2009).

${ }^{11}$ Compare Lucian Bebchuk, The Case for Shareholder Access to the Ballot, 59 BuS. LAW. 43 (2003), with Martin Lipton \& Steven A. Rosenblum, Election Contests in the Company's Proxy: An Idea Whose Time Has Not Come, 59 Bus. LAW. 67 (2003), and Letter from Seven Law Firms to Elizabeth Murphy, Sec'y, SEC on Facilitating Shareholder Director Nominations (Jan. 19, 2010) [hereinafter Seven Law Firm Letter].

${ }^{12}$ See Mark J. Roe, A Political Theory of American Corporate Finance, 91 ColuM. L. Rev. 10 (1991); MARK J. Roe, STRONG MANAGERS, WeAK OWNERS: The POLITICAL RoOTS OF AMERICAN CORPORATE FINANCE (1994). See also Lucian Bebchuk \& Zvika Neeman, Investor Protection and Interest Group Politics, 23 REV. FIN. STUD. 1089 (2010); Marcel Kahan \& Edward 
actions can be better explained in terms of Delaware, encouraged by its managerial interest inputs, positioning itself in relation to the potential outcomes in Washington, which in turn are affected by Washington's primary interest group inputs, which differ from Delaware's. The shareholder power initiatives of the past decade fit this explanatory structure much better than they fit a state competition structure.

Hence, in this Article, I examine the SEC rules and Delaware's new shareholder voting statute in order to evaluate, I believe for the first time, two related questions: First, is Delaware's statute best understood as a reaction to Washington or as a manifestation of state competition? Second, can we contrast the differing interest group inputs into Delaware and Washington lawmaking? Did the two interact, with one trying to influence the other, and did that influence flow from Delaware to Washington as well as from Washington to Delaware?

Both questions yield answers inconsistent with typical jurisdictional thinking for corporate lawmaking. It's hard to see interstate, horizontal, competitive pressure as anywhere nearly as strong as Washington's vertical pressure on Delaware. There's considerable evidence that several influential Delaware players wanted Delaware to provide an alternative to the mandatory voting rules that were emerging - and did emerge - in Washington, and they wanted to use Delaware's law to slow Washington from strengthening the shareholder vote. Delaware media reported during the 2008 election that leading Delaware "lawyers are calling for Delaware to throw water on the fire [of federal corporate lawmaking activity] before the national election by tweaking the state's corporate law to address growing concerns among stockholders . . . ., 13

True, not everyone was acting strategically. Many surely came to their own judgment of what was best for corporate structures, and some actions represented long-held views, uninfluenced by immediate strategic considerations. But political pressures and interests can affect which rules are selected among several that are plausible, can affect the thinking even of the public-spirited, and can be used for self-interested purposes even if the corporate statutes emerged from a legislature of outstanding public servants acting for fully public-spirited reasons. It must be that high-road views of the merits were important, but we cannot fully understand the corporate lawmaking

B. Rock, Symbiotic Federalism and the Structure of Corporate Law, 58 VAND. L. REV. 1573 (2005); Jonathan Macey \& Geoffrey Miller, Origin of the Blue Sky Laws, 70 TEX. L. REV. 347 (1991).

${ }^{13}$ Maureen Milford, Delaware's corporate dominance threatened-Federal intervention could put at risk a third of state's budget, THE NEWS JOURNAL, Mar. 2, 2008, at A1. 
process here thus far without understanding the interests in play. The statefederal interaction in corporate lawmaking has a political economy dimension to analyze, and I analyze that dimension here.

A roadmap for this article is as follows. In Part I, I briefly review the classical scholarship on horizontal, state competition. In Part II, I show how the substantial SEC and congressional activity vis-à-vis shareholder voting during the past decade challenges the classical view: the primary action was in Washington, state-based lawmaking emerged late not early, and the state lawmaking that emerged can best be seen as responding to Washington, not to other corporate lawmaking states.

In Part III, I scrutinize the new Delaware shareholder voting statute to reveal its tight mechanical limits on shareholders' capacity to really obtain costeffective influence in electing directors. Those limits are substantial and much tighter than the rules the SEC promulgated. In Part IV, I hypothesize several explanations for Delaware's movement during the decade-from a publicspirited foray to recapture the corporate high ground from federal corporate lawmakers, to raw interest group capture with a deeply clever constitutional litigation strategy - and bring forward supporting evidence for each. Each explanation for state-based corporate lawmaking here interacts with the Washington action on shareholder voting, but each does so in a differing way.

In Part V, I re-animate the Delaware-SEC political economy story in terms with which political scientists would be comfortable. I show how the political economy differences between state corporate lawmaking and federal corporate lawmaking map onto differences inside the large American corporation. Then, lastly, I conclude.

\section{The Classical View of American CoRporate LaWmaking}

The traditional model of American corporate lawmaking has long been that states compete to garner corporate charters, which yields the winning state significant fees. Delaware, where more than a majority of America's public firms are chartered, covers about a quarter of its annual budget directly via corporate chartering fees, and even more indirectly. Views differed - and those differences were aggressively expressed - on whether state competition for chartering fees drove corporate law toward or away from fairness and efficiency. Either way, the long-shared consensus was that state-to-state competition was central to core American corporate lawmaking. 
The most vocal early state-to-state competition camp saw the race as pernicious. Justice Brandeis viewed the competitive dynamic as one that induced states to allow firms to grow overly large for managers' and shareholders' benefit, to the detriment of the American public and the American economy. State competition, he said in 1933, prodded states to cede their corporate law to private corporate interests at the expense of the public interest, in order to garner incorporations and franchise revenue. ${ }^{14}$

Decades later in the 1970s, William Cary, having finished up as chair of the SEC in the 1960s, returned to academe and argued that the major threat to high-quality corporate law in the United States was low-quality state corporate lawmaking. ${ }^{15}$ In a prominent article, he concluded that Delaware case law gave far too much discretion to insiders, saw the franchise fees as motivating Delaware's favoring of insiders because insiders decided where the firm would buy its charter, and called on Congress to enact minimum corporate standards for large firms in the United States to remedy that race to the bottom. ${ }^{16}$

Race-to-the top replies followed. ${ }^{17}$ Ralph Winter, then at Yale, said that states could not systematically diminish their firms' efficiency. If a state did, product and capital market competition would degrade its firms' quality and profitability, while firms incorporated elsewhere would prosper. At the limit, firms in bad-corporate-law jurisdictions would be bought up by firms in goodcorporate-law jurisdictions. ${ }^{18}$ (In his original formulation, he had state-made takeover laws not as part of the race itself.) Important expansions and empirical work followed. ${ }^{19}$

Delaware players may have long been uncomfortable with the state competition literature. Surely the race to the bottom portrait that William Cary and much of the subsequent literature offered was unflattering. But even the race to the top view could readily have been resisted as unrealistic. Judges, legislators, and corporate leaders go to work daily and surely do not have their minds tuned primarily to jurisdictional impact when deciding what to do. For many, professionalism in doing one's job well defined their core motivations. Even the race to the top could have been offensive in suggesting that publicminded professionals would not do their job well without the spur of jurisdictional competition.

\footnotetext{
${ }^{14}$ See Louis K. Liggett Co. v. Lee, 288 U.S. 517, 548-65 (1933) (Brandeis, J., dissenting in part).

${ }^{15}$ See Cary, supra note 7, at 670-704.

${ }^{16}$ Id. at 701 .

${ }^{17}$ For classic views on the race to the top, see generally sources cited supra notes 7 and 8 .

${ }^{18}$ Winter, supra note 6 , at 256.

${ }^{19}$ See generally supra notes 7 and 8 .
} 
Still, if the notion of a tight race were loosened, the analytics could have better focused on the constraints that corporate professionals would hit from time to time. But, regardless, the long-held consensus that state competition was the core driver (with consensus lacking on the driver's normative impact) was challenged in Marcel Kahan's and Ehud Kamar's 2002 Stanford Law Review article, providing evidence that other than Delaware, no state is now seriously trying to garner the corporate business. Delaware had, and has, a monopoly. I showed in Delaware's Competition that over the course of $20^{\text {th }}$ century, the major issue in corporate law frequently gravitated into the federal arena, such as the merger litigation in 1980s under the Williams Act, or the proxy rules in the 1950s under the SEC rulemaking, or the independent director initiatives in the 1960s at the New York Stock Exchange-initiatives that emerged after SEC prodding. Washington has been a significant player in corporate governance and always is there with the potential to be a more significant player ${ }^{20}$ Here I examine the classic and disruptive views, see the disruptive views as more consistent with the past decade than the classic view, and take the new views a step further: Delaware state-lawmaking not only interacts closely with Washington corporate lawmaking, but can also be positioned to affect the federal output, and political economy differences between Delaware and Washington largely explain the nature and background strategy motivating much of the federal-state interaction. The vertical impact is two-way. If one needed a media-oriented phrase to summarize the thesis, it could be "Delaware strikes back."

\section{The SEC Post-2000 Action to Reshape PoWer Inside THE LARGE AMERICAN FIRM}

\section{A. Shareholder Voting Basics}

Consider shareholder voting to elect the company's board of directors. As is well known in the public corporation world, the incumbent board solicits votes from shareholders in the annual board election, and it does so at the company's expense. The board typically nominates its incumbent members, or its chosen successors, to be voted on at the company's annual meeting, usually unopposed.

Voting solicitation costs are not trivial. Although shareholders who want to run their own nominees against the ongoing directors are free to solicit votes from the company's other shareholders, they must pay for their own

\footnotetext{
${ }^{20}$ Roe, Delaware's Competition, supra note 10, at 598.
} 
solicitations, which are typically expensive. Those expenses, and the legal risks entailed, deter most shareholders from contesting board elections, even for boards of troubled companies. The shareholders pay the hefty expenses of soliciting votes for a new board, but cannot be sure they will ever be reimbursed by the company, and, even if they succeed, the benefits of the new directors are divided among all shareholders and not captured solely by the activist shareholders.

This sharp asymmetry in expense-bearing is at the core of the power allocation in the American public corporation. It puts corporate power disproportionately in the hands of incumbent directors, not stockholders. ${ }^{21}$

\section{B. Back and Forth in Washington: 2002-2011}

In the past decade, those shareholder voting basics came under attack. After the Enron scandals at the beginning of the decade, Washington enacted the Sarbanes-Oxley Act to revise American corporate governance law, and the SEC examined whether to also revise its rules to permit activist shareholders easy, cheap access to the company's proxy statement so as to lower the costs of shareholder activism, toward the end of making managers and boards more accountable and, they hoped, more scandal resistant. SEC Chair William Donaldson put shareholder access to nominate on the modern SEC agenda in 2003 , and it was seen as a major and inevitable post-scandal reform. ${ }^{22}$ Corporate law was being considered, but it was being considered in Washington not states.

Easy access proved controversial, as scandals faded from memory and the media. ${ }^{23}$ The proposed rules failed, dropping off the SEC agenda until the next SEC Chair, Christopher Cox, put them back on in 2005. But his Commission also decided not to promulgate access. ${ }^{24}$ The subsequent and

${ }^{21}$ This is the long-received wisdom, set forth in basic corporate analytic materials. See, e.g., William T. Allen, Reinier KraAkman \& Guhan Subramanian, Commentaries AND CASES ON THE LAW OF BUSINESS ORGANIZATION 169-70 ( $3 \mathrm{~d}$ ed. 2009). The paucity of true proxy contests has been confirmed recently in Lucian A. Bebchuk, The Myth of the Shareholder Franchise, 93 VA. L. REV. 675, 685-86 (2007).

${ }^{22}$ See Charles M. Nathan, The Battle for Shareholder Access: the Current State of Play, The HARV. LAW SCH. FORUM ON CORP. GOVERNANCE AND FIN. REgULATION [hereinafter HLS FORUM) (May 30, 2009), http://blogs.law.harvard.edu/corpgov/2009/05/30/the-battle-forshareholder-access-the-current-state-of-play/.

23 See Ted Allen, One Year Later, Shareholder Access Remains Stalled at SEC, INSTITUTIONAL INVESTOR, Oct. 15, 2004, available at http://www.institutionalinvestor.com /Popups/PrintArticle.aspx?ArticleID=1028793.

${ }^{24}$ See Shareholder Proposals Relating to the Election of Directors, Exchange Act Release No. 56,914 (Jan. 10, 2008). 
current SEC Chair, Mary Schapiro, quickly announced after assuming her position that shareholder proxy access was high on her Commission's agenda. ${ }^{25}$ The economic and political atmosphere of a national economic recession and Wall Street financial deterioration made it plausible again that the SEC would act, which in August 2010 it did.

During the same 2003 to 2008 time span, Delaware law was seen as hostile to shareholder access. It was seen as barring activists from either seeking such access to the company's proxy statement directly or getting a clean shareholder vote to permit such company-paid access for outside activist shareholders. ${ }^{26}$ Activist shareholders sought bylaws that would enable shareholder access, and Delaware lawyers opined that Delaware law barred access, so boards could readily refuse - and did refuse - to include such proposals to unseat themselves in the companies' election materials. Shareholder activists saw Delaware law as an impediment and SEC rulemaking as a solution. Managerial interests vigorously opposed SEC action on access, largely successfully, until 2009 and 2010.

1. A done deal. The Enron, WorldCom, and related scandals dominated the business law reform agenda in the early years of the decade. Congress enacted Sarbanes-Oxley in the summer of 2002, making the first major piece of corporate law in the decade an act of Congress, not an amendment to a state corporations code. Simultaneously, the SEC announced that shareholder access to the company's voting apparatus would be a core reform for it to pursue. In the immediate wake of the Enron scandal, the media saw the proposal as a done deal, likely to be in place by the 2004 proxy season. ${ }^{27}$

But reform sentiment subsided. Corporate, particularly managerial, spokespeople argued against access to the SEC and elsewhere. ${ }^{28}$ The views of the SEC's chair, Donaldson, softened, White House pressure against enhancing shareholder power was said to have been brought to bear, and he eventually

\footnotetext{
${ }^{25}$ Proxies: Schapiro, Carrying Through on Promises, Directs Staff to Draft Proxy Access Proposals, 41 SEC. REG. \& L. REP. (BNA), at 448 (Mar. 16, 2009).

${ }^{26}$ Brett H. McDonnell, Shareholder Bylaws, Shareholder Nominations, and Poison Pills, 3 BERKELEY BUS. L. J. 205, 221-22 (2005).

${ }^{27}$ Stephen Labaton, S.E.C. to Revise Election Rules for Directors, N.Y. TIMES, Oct 1, 2003, at C1.

${ }^{28}$ See Lipton \& Rosenblum, supra note 11; Section of Business Law of the Am. Bar Ass'n, Task Force on Shareholder Proposals of the Committee on Federal Regulation of Securities, Report on Proposed Changes in Proxy Rules and Regulations Regarding Procedures for the Election of Corporate Directors (2003) (“ABA Task Force”); Judith Burns, CEOs Blast SEC Proxy Plan, While Unions Praise It, DOW JONES NewswirES, Oct. 8, 2003. For views favoring access, see Lucian A. Bebchuk \& Scott Hirst, Private Ordering and the Proxy Access Debate, 65 BuS. LAW. 329-60 (2010), and sources cited therein.
} 
decided not go forward. ${ }^{29}$ The SEC suspended action on its proposal. In little more than a single post-Enron year, shareholder access went from being widely seen as a done deal at the SEC to dead. ${ }^{30}$

Delaware during this period did nothing to facilitate shareholder access; with the SEC retreating, Delaware had little basis to feel vertical pressure to facilitate it.

2. Cox renews, then withdraws, the SEC initiative. Christopher Cox succeeded Donaldson as chair of the SEC and promptly put the shareholder vote back on its agenda. Then, as the regulatory proposal percolated at the SEC, the Second Circuit Court of Appeals reset the SEC's thinking and action.

The old SEC rule on shareholder voting (Rule 14a-8) allowed company managers to keep a shareholder proposal out of the company's voting documents if the proposal was "relate[d] to an election." (The rule allowed activists to get advisory votes on, say, environmental improvements at the target company, but could not be used for core corporate governance election activity.) Insurgents had argued that the "relates to an election" exclusion only excluded voting on new directors, not voting on election rules, such as rules to give insurgents access to the company's voting machinery in future elections. But the SEC in recent years said that $14 \mathrm{a}-8$ relates to both an election at hand and votes about election rules, allowing management to exclude proposals to change the voting rules.

Then, in 2006, the Second Circuit ruled that the SEC's election exclusion in its Rule 14a-8 barred management from excluding from the company voting materials shareholder bylaw proposals that would govern elections procedures. ${ }^{31}$ The board could exclude actual nominations under the "relates to an election" phrase, said the court, but not proposals for rules to govern future corporate elections.

That ruling induced the Cox SEC in mid-2007 to reconsider access more quickly than it otherwise might have. It put forth two drafts for public comment. The first would be a blow to the insurgents, by explicitly allowing boards to

\footnotetext{
${ }^{29}$ Stephen Labaton \& Jenny Anderson, S.E.C. Chief, Under Cross-Pressure, Sees Some Modest Changes, N.Y. TIMES, Feb. 10, 2005 ("Calls from some administration officials . . have cast a shadow on Mr. Donaldson's agenda"); Stephen Labaton, S.E.C. Rebuffs Investors on Board Votes, N.Y. TIMES, Feb. 8, 2005, at C2 ("Mr. Donaldson . . . has come under heavy pressure from the Bush administration . . . ."); cf. Alan Murray, Business Groups Are Seeking Ouster of SEC's Donaldson, WALL ST. J., Dec. 14, 2004, at A4 ("Top business groups in Washington have launched a quiet campaign to persuade the White House to dump ... Donaldson. The groups argue that the [SEC's] post-Enron crackdown on big business has gone too far ....”).

${ }^{30}$ Compare Labaton, supra note 27, with Stephen Labaton, S.E.C. Member Says Agency Has Bowed To Executives, N.Y. TIMES, Oct. 9, 2004, at B1.

${ }^{31}$ AFSCME v. AIG, Inc., 462 F.3d 121, 123 (2d Cir. 2006).
} 
exclude shareholder proposals on voting mechanisms. The second would have been a blow to managerial opponents of access, by requiring that boards include voting mechanism proposals.

Eventually, in November 2007, the Cox SEC promulgated the exclusion, not the expansion. ${ }^{32}$ Access was dead again in Washington.

During this period too, Delaware did nothing to facilitate shareholder access and, with access dead in Washington, there was no vertical pressure for it to do so. ${ }^{33}$

3. Schapiro re-starts shareholder access. After the 2008 election, Mary Schapiro became chair of the SEC and she pushed shareholder access back onto its agenda. ${ }^{34}$ Access looked likely to be promulgated quickly. "Chairman Schapiro has made clear her interest in empowering shareholders to improve corporate governance[.] . . That Schapiro came out so quickly on proxy access, less than two months into her chairmanship did not come as a surprise." ${ }^{" 35}$ The SEC simplified its earlier cumbersome 2003 proposal. The 2007-2008 financial crisis had put business reform back on the agenda (even though proxy access issues did little to directly explain the financial crisis). The sharpest political critique of access - that it particularly helped state pension funds and other shareholder activists who were Democratic constituents-was not a compelling counterargument in a Democratic administration in Washington. ${ }^{36}$

The Delaware legislature then reacted un 2009, passing a new shareholder voting statute, one that managerial and board interests argued, as we see with more precision in Part III, made the SEC's proposed rules a mistake, or at least redundant. Vertical pressure might well have been felt to have increased. And indeed after the 2008 election, the Delaware Corporate

\footnotetext{
${ }^{32}$ Shareholder Proposals Relating to the Election of Directors, Exchange Act Release No. 56,914 (Jan. 10, 2008).

${ }^{33}$ While I focus next on the legislative reaction, the Delaware Supreme Court did react when prodded by SEC certified questions on proxy access. In Computer Associates v. AFSCME Emp. Pension Plan, 953 A.2d 227 (Del. 2008), the court indicated that access rules could be a proper for shareholder action, but the rules needed to be subject to a board-controlled fiduciary out. More on that below, see infra pp. xxx-yyy .

${ }^{34}$ See Facilitating Shareholder Director Nominations, Exchange Act Release No. 60,089 (June 10, 2009).

${ }^{35}$ Yin Wilczek, Proxy Access: Schapiro Directs Staff to Draft Proxy Access Proposals, CORP. COUNSEL WEEKLY (BNA), Mar. 11, 2009, at 1-2.

${ }^{36}$ Cf. Joseph A. Grundfest, The SEC's Proposed Proxy Access Rules: Politics, Economics, and the Law, 65 BUS. LAW. 361, 365 (2010).
} 
Law Council, which advised the legislature to enact $\S \S 112$ and 113, did have Washington on their mind when working on shareholder access. ${ }^{37}$

4. Schapiro's SEC promulgates shareholder access. As expected, the SEC in August 2010 promulgated two shareholder voting rules. One, Rule 14a8 , was optional to the company: firms had to allow appropriately qualified shareholders access to the company voting machinery to elect directors and to determine the firm's voting rules. The second one, Rule 14a-11, required companies to give access to the company's voting machinery for shareholders owning $3 \%$ of the firm's stock for several years, to nominate up to one-quarter of the board. That rule applied to all companies and could not be watered down by shareholder and board action. Corporate insiders had vociferously opposed the rule when the SEC considered $\mathrm{it}^{38}$ and immediately challenged the expansive rule, 14a-11, on many grounds, including that it denigrated the state law in-place on the subject. In July 2011, the D.C. Circuit Court of Appeals struck down Rule 14a-11. ${ }^{39}$

\section{Delaware ReACTS: 2009}

The decade's major corporate law reforms were proposed, debated, promulgated, and, for Rule 14a-11, struck down at the federal level, not the state level. It was a process of lawmaking that the authors of classic views of the horizontal state-to-state competitive race for corporate lawmaking would not recognize, because the primary action was in Washington, not in the states, and it certainly was not honed in horizontal, state-to-state competition. Finally, near the end of the decade in 2009, Delaware passed a shareholder voting rule, shortly after its Supreme Court answered SEC-certified questions on the validity of shareholder bylaws on election rules. Delaware's late-decade legislation means that we have to rotate the direction of the classical view of jurisdictional competition a full 90 degrees: instead of the jurisdictional interaction occurring

${ }^{37}$ Larry Hamermesh, Conference communication, Nov. 11, 2011 (panel on Delaware corporate lawmaking and jurisdictional competition, at Columbia Law School conference entitled The Delaware Court of Chancery: Change and Continuity).

${ }^{38}$ Since the rules only allowed $25 \%$ of the board to be elected via access, the vociferous opposition needs some explanation. One might be managers' philosophical view as to who should run the corporation. Another might be that directors and their agents viewed $25 \%$ access as the opening bid. During future corporate crises, policymakers' reforms would regularly be to expand access, eventually reaching a board majority. The multi-decade expansion of the number of required independent directors is parallel.

${ }^{39}$ Bus. Roundtable and Chamber of Commerce of U.S. v. SEC, 647 F.3d 1144 (D.C. Cir. 2011). 
on the state-to-state horizontal axis, it was happening on the federal-state vertical axis.

What's more, the interaction had deep, important political economy roots lying beneath the law-on-the-books written. There's a political economy interaction of each level strategically influencing the other.

First, to better understand the political economy interaction in a few moments, let's examine the Delaware statutory mechanics. The Delaware mechanisms contrast with the SEC rules, as the Delaware mechanisms are, for shareholders, much weaker than the SEC's. From the differences in strength, we can extrapolate potential differences in political inputs. With the extrapolations and differences in mind, we can examine the then-contemporary views of the actors and astute involved observers to see if the contemporary views map onto a deeper political economy story emerging from differences in interests at the two political levels. They do.

\section{A. Delaware Access: If and Only If Provided in the Bylaws}

Until 2009, Delaware lawyers interpreted Delaware law as impeding shareholders from getting access to the company voting machinery for shareholder nominations. ${ }^{40}$ Activists who sought bylaws to permit shareholder access were blocked by Delaware lawyers' opinions that Delaware law barred access. Boards refused to include such proposals to unseat themselves in the companies' election materials. Activists saw Delaware law as a roadblock that they wanted the SEC to break open.

In March 2009, the Delaware legislature amended its corporate law to allow shareholders access to the company's proxy solicitation. The business press reported that "the [year's] most significant change [for Delaware corporate law] is the amendment allowing investors to include their director nominees in the same proxy document mailed by companies to shareholders, making it easier for them and less expensive." ${ }^{, 41}$ The provision was the lead

${ }^{40}$ McDonnell, supra note 26, summarizes the lawyers' anti-access opinions.

${ }^{41}$ Joseph A. Giannone, Proposed Delaware Law Changes Expand Proxy Access, REUTERS (Feb. 27, 2009), http://www.reuters.com/article/2009/02/27/corporategovernance-delawareidUSN2736708820090227 (stating that the financial press saw Delaware as acting positively in enacting shareholder access, with its proposal resonating with the SEC's agenda).

Delaware's action interacts with the classical, state-competition-based views of corporate lawmaking. In the classical view, state competition produced weak, or no, shareholder access to the company's proxy statement, either due to efficiency (race to the top) or insider-dominition of state lawmaking (to the bottom). But, in the face of persistent federal forays to promulgate access, the Delaware legislature enacted access rule in 2009. 
section in the Delaware March 2009 bill to amend Delaware corporate law, which Delaware's legislature passed and which its governor signed into law.

The law was simple. The state's corporate law would now permit, via its new Section 112, shareholder access to the company's proxy solicitation, if and only if the corporate by-laws provided for that access:

The bylaws [of a Delaware corporation] may provide that if the corporation solicits proxies with respect to an election of directors, it may be required . . . to include in its proxy solicitation materials . . . in addition to individuals nominated by the board of directors, 1 or more individuals nominated by a stockholder. $^{42}$

Why did Delaware enact access? And why did it enact the less than straightforward access statute that it did, one that superficially seems to favor corporate governance insurgents - but, as we shall see shortly, does not? Why did Delaware, unfriendly to more shareholder power in board elections at the beginning of the decade, and often thought to be board-friendly, come to enact a voting access statute at the decade's end, despite that boards and their organizations, like the Business Roundtable and the Chamber of Commerce, as well as their law firms, had strongly opposed shareholder access for board elections for most of the decade?

Some hypotheses emerge from examining the statute.

\section{B. From Where Do Bylaws Come?}

How much power does the Delaware statute really transfer from boards to shareholders? True, managerial proponents said, in a widely-distributed memorandum in the business world, that Delaware access via $\S 112$ was more than enough for governance activists and thereby made SEC action superfluous:

Importantly, the states have proven themselves responsive to legitimate calls for reform. Delaware has recently amended its corporate statute to permit corporate boards or stockholders to provide for stockholder access to the company's proxy materials for director elections. ${ }^{43}$

${ }^{42}$ Del. Code ANN. tit. 8, § 112 (West 2009).

${ }^{43}$ Memorandum from Martin Lipton, Jay W. Lorsch \& Theodore N. Mirvis, A Crisis is a Terrible Thing to Waste: The Proposed "Shareholder Bill of Rights Act of 2009" Is a Serious Mistake 3 (May 12, 2009), available at http://www.wlrk.com/webdocs/wlrknew/WLRKMemos /WLRK/WLRK.16657.09.pdf (emphasis added). 
But consider the statute's conditionality: The statute permitted access, but only if authorized in the firm's by-laws.

That limit superficially seems merely mechanical, not an actual allocation of power - for shareholders to get access, they just need to make the bylaws authorize access. But that bylaw proviso allocates power between shareholders and boards and does so in the traditional, board-friendly way. It does so because bylaws arise in two ways: first, from the board itself, and second via a shareholder vote.

1. The board. The typical way to get a bylaw is that the board of directors re-writes the company's bylaws. But expecting the target board to freely write an access bylaw when requested to do so is unrealistic: the insurgents are targeting the board itself for change. Yet, under the Delaware statute, it's the targeted board that would first be asked to authorize the mechanism for its own demise.

It's possible that there are such directors, but boards generally seek autonomy. True, if the board comes under shareholder pressure via other means for shareholders to assert authority, it might accede to an access bylaw. Corporate governance ratings groups might give an extra ratings point to companies with access bylaws. And boards under pressure do compromise, and compromises can involve corporate election rules. In recent years, boards under pressure have ended self-entrenchment mechanisms such as staggered boards. But if a board-promulgated access bylaw would be a convenient compromise, the shareholder power to press for it must come from elsewhere. Delaware's access law is not an independent source of shareholder power, but an authorized compromise point if activist shareholders have other ways to pressure a target board. $^{44}$

2. The shareholders, but via a proxy fight. Shareholders can themselves vote to change the bylaws. But how do they get to vote on new bylaws? The insurgents must first solicit votes from the other shareholders. If a majority of the shareholders vote in their favor, the bylaw authorizing access becomes part of the company's governing rules.

${ }^{44}$ Even for features not entailing director self-interest, "[p]ublicly traded corporations rarely use the nearly absolute freedom afforded them to . . . deviate from the default terms of state corporation law." Henry Hansmann, Corporation and Contract, 8 AM. L. \& ECON. REV. 1, 1 (2006).

Delaware also authorized company bylaws to reimburse insurgents their expenses. To get a bylaw that authorizes reimbursing insurgents who challenge incumbents, targeted incumbents can authorize that the insurgents be reimbursed. Again, this is not ordinarily likely. 
That is, to obtain a structure that would allow a cheap proxy contest, the insurgents need first to launch, pay for, and win an expensive proxy contest of approximately the same sort that they are seeking to avoid. An earlier generation would recognize this as a "Catch-22."

Hence, Delaware's proxy reform was not immediately very useful for insurgents. This dead-end has not, as far as I am aware, been a focus of analysis of the Delaware change. ${ }^{45}$ Indeed, one might ask whether many shareholders would want to use an expensive contest so as to facilitate a cheap one. If the shareholder is willing to pay for the expensive contest for a governing rule, it might just as well do a full-scale proxy fight for control of the board. ${ }^{46}$

3. The Delaware solution. The Delaware legislature could have authorized insurgent shareholders to get an access bylaw proposal put in place without their having to launch a full-scale proxy contest. The new sections 112 and 113 could have had a simple provision, along these lines:

In any solicitation of proxies by the company, the company must include for shareholder vote any bylaw proposed by $10 \%$ of its shareholders 60 days prior to the solicitation. Shareholders, but not the board acting alone, may alter the necessary percentage and timing in the foregoing sentence, via the company bylaws.

That is, Delaware lawmakers could have required companies to give shareholders access to the company's voting machinery for bylaw voting mechanism proposals - an "access for access" rule. Or, Delaware lawmakers could have made access the default rule, until shareholders altered it, up or

${ }^{45}$ Cf. Memorandum from Sullivan \& Cromwell to Clients, Delaware Adopts Amendments to the Delaware General Corporation Law Relating to Corporate Governance (Apr. 28, 2009); Lipton, Lorsch \& Mirvis, supra note 43. In the Business Roundtable's challenge, it asserted that the SEC's Rule 14a-11 upset state law because it "mandate[s] 'access' to company proxy materials, which Delaware law . . . authorize[s] shareholders to adopt by choice."). Opening Brief of Petitioners at 9, Bus. Roundtable and Chamber of Commerce v. SEC, 647 F.3d 1144 (D.C. Cir. 2011) (No. 10-1305), 2011 WL 2014800. While accurately describing the attacked feature of the proposed SEC rule (it mandates access), the description of Delaware law could mislead, as Delaware law does not formally facilitate shareholder choice, due to its "Catch 22" structure.

${ }^{46}$ Cf. Marcel Kahan \& Edward B. Rock, The Insignificance of Proxy Access, 97 VA. L. REV. (forthcoming Oct. 2011), (describing weak power of board members elected via access instead of via regular proxy voting) (manuscript at 46-49).

To be sure here, elections for directors and for by-laws are similarly but not identically motivated. A process-bylaw could be cheaper for activists to get if governance associations endorse it as a good, across-the-board, general governance reform. Insurgents may have trouble persuading some stockholders that the insurgents' directors are able enough, or that the situation is dire enough to require replacing the incumbent board. On the other hand, the benefits to shareholders of a process-bylaw may be low enough to dissuade them from trying. 
down. But Delaware did neither. It left the board-centered procedural hurdles to access in place, and those hurdles approximate the very hurdles access is designed to lower for shareholders, the very hurdles that allocate power in boards in the large American public firm. ${ }^{47}$

In the first proxy season after the Delaware access enactment, no shareholder seems to have solicited shareholders to approve a $\S 112$ access bylaw. ${ }^{48}$ The statutory analytics above suggest a major reason why.

4. The SEC solution: Rule 14a-8. The SEC regulates proxy solicitations under Section 14 of the Securities Exchange Act of 1934. In August 2010, the SEC amended 14a-8 to allow access for shareholder voting on bylaw amendments. Its new rule, which is much friendlier to activist shareholders than its prior rule, ${ }^{49}$ makes Delaware $\S 112$ potentially useful for shareholders, and it is a rule that state law could have accomplished, to shift power from boards to shareholders. But 14a-8-type "access for access" did not happen in the states. It happened in Washington.

\section{Concrete Public Choice, Federal-State Explanations}

Since Delaware's statute is not a powerful shareholder-oriented tool and on its surface did what Delaware had once been thought to always allow (board and shareholder control of the election rules through the company's bylaws), why did it bother, especially when the SEC was considering stronger access?

Ascertaining Delaware's motives through the usual technique of parsing legislative history is not possible, because there is no formal legislative history. The Delaware Corporate Law Council recommended that the legislature amend the state's corporate law, but it did not issue a report, just the text of a draft statute. The legislature did not hold hearings or write a legislative report, but passed that proposed statute. There is no record of a legislative debate.

Intentions, however, can be divined by examining contemporary "testimony" of Delaware players and corporate law leaders' statements in

${ }^{47}$ Corporate lawyers' interests should not be ignored. Delaware's corporate lawyers, who strongly influence Delaware corporate law-making, should do better with tailor-made access rules, because they would typically require serious lawyering time, in contrast with one-size-fits-all generic rules, which would be cheaper to implement.

${ }^{48}$ Kahan \& Rock, supra note 46, at 15 n.69.

${ }^{49}$ Shareholder Proposals Relating to the Election of Directors, Exchange Act Release No. 56,914 (Jan. 10, 2008) (amending Rule 14a-8 and clarifying that election format proposals are not proper for shareholder proposals); cf. AFSCME v. AIG, Inc., 462 F.3d 121, 123 (2d Cir. 2006) (inducing SEC clarification of prior 14a-8 rule). When the Business Roundtable challenged the SEC on Rule 14a-11, the SEC self-stayed both 14a-11 and 14a-8. The DC Circuit struck down 14a-11. The SEC thereafter lifted its stay on $14 a-8$. 
formal SEC submissions, in briefs challenging the SEC rules, in Council member's subsequent statements, and in the media. Then, we can line up the leaders' expressed views with our construction of the statute and examine incentives and motives. If expressed views, construction of the two rule sets (Delaware $\S \S 112$ and 113, on one hand, and the SEC's 14a-8 and 14a-11 on the other), and the interests of the most influential corporate groups at each political level mesh together in a consistent political economy story, we have a strong basis to see those political economy pulsations as being a motivating force behind the statutes and rules.

To be sure here, the merits, a desire for statutory clarity, and interests all seem to have been in play, presumably in different degrees for different players. I focus primarily on the interests, but that does not mean that other, publicspirited motivations were absent or even, for many players, dominant.

The most interesting, and most Machiavellian, hypothesis that could emerge is that Delaware's $\S 112$ served to forestall the strongest, or all, of the SEC's actions on shareholder voting. The hypothesis could be that such considerations motivated the statute or, less Machiavellian, that interests used the statute for that purpose, even if the statute was otherwise propelled into law.

Indeed, the Delaware corporate bar submitted to the SEC the bar's view that, given the existence of Delaware's $\S 112$, the SEC need not promulgate an access rule, that Delaware-based flexibility was superior to a Washington-made rule, and that an SEC-promulgated rule would "undermine ... the state system of [American] corporate governance." intimately involved in the drafting and passage of Delaware corporate law.) Moreover, both Delaware players and savvy corporate lawyers stated that Washington's efforts motivated Delaware's strategic actions and interests: "The [access] amendments to the Delaware General Corporate Law respond[ed] to . . . SEC rule-making initiatives relating to stockholder access," said a corporate law authority and an influential former chief justice of the Delaware Supreme Court. ${ }^{51} \mathrm{~A}$ leader in the national corporate bar, Ted Mirvis, said that Delaware sought "to forestall these attempts [at the SEC and in Congress] to further

${ }^{50}$ Letter from Del. State Bar Ass'n to Elizabeth M. Murphy, Sec'y, SEC on Facilitating Shareholder Director Nominations (July 24, 2009), available at http://www.sec.gov/comments/s710-09/s71009-65.pdf ("Delaware letter").

51 E. Norman Veasey \& Christine di Guglielmo, Delaware Legislature Addresses Shareholder Access and Adopts Other Important Corporate Governance Provisions, Metropolitan CORP. COUNSEL, May 2009, at 48, available at http://www.metrocorp counsel.com/pdf/2009/May/48.pdf; Leo E. Strine, Breaking the Corporate Governance Logjam in Washington: Some Constructive Thoughts on a Responsible Path Forward, 63 Bus. LAw. 1079, 1081 (2008). Below I make clear that reaction is itself normatively neutral: Delaware players may want to do a better job and have confidence that they can. 
federalize corporate law." ${ }^{52}$ With Delaware having enacted access, Washington need not do more.

Fully understanding why Delaware acted is speculative. A simple, highroad interpretation is that over time Delaware became convinced that access was a good idea, that enough boards and managers might need the wake-up call that shareholder proxy access could give them, and that any downside of access could be contained. Other Delaware players long thought that non-mandatory access was good policy and perhaps saw their moment to push forward their view. ${ }^{53}$ In the financial crisis atmosphere prevailing when the statute passed, Delaware's corporate players may have decided they had to act, if only to stay relevant. And, if access was coming anyway, responsible Delaware lawmakers could believe that they would implement it better than federal regulators. Perhaps in the back of some actors' minds was the risk that a backlash against corporate and financial interests during the ongoing economic and financial crisis could have turned against Delaware if the state stayed passive.

Less sympathetic public-choice-based hypotheses are also available. We assess them all, from innocuous, to high-road and public-spirited, to Machiavellian.

52 Theodore Mirvis, Strategies for the New Reality of Shareholder Proxy Access, HLS FORUM (May 14, 2009), http://blogs.law.harvard.edu/corpgov/2009/05/14/strategies-for-the-newreality-of-shareholder-proxy-access/ (emphasis added); cf. Lipton, Lorsch \& Mirvis, supra note 43, at 3 ("Importantly, the states have proven themselves responsive to legitimate calls for reform. Delaware ....") (emphasis added); David Marcus, Laster's Moment, THE DEAL MAGAZINE, Apr. 2, 2010, available at http://www.thedeal.com/magazine/ID/034047/featuresold/laster'smoment.php (stating that a major, savvy Delaware player "suggested [two years ago] that Delaware concede proxy access as a way to blunt calls for shareholder say-on-pay"). The drafters of the other major state-based corporate lawmaking organization-the Model Business Corporation Act-brought forward their similar model shareholder access law. See Comm. on Corporate Laws, ABA Bus. Law Section, Report on the Roles of Boards of Directors and Shareholders of Publicly Owned Corporations and Changes to the Model Business Corporation Act-Adoption of Shareholder Proxy Access Amendments to Chapters 2 and 10, 65 BUS. LAW. $1105,1105,1111,1116(2010)$.

${ }^{53}$ Leo Strine, for example, has consistently pushed forward a $14 a-8$ rule as the best way to go, as have other leaders. See Strine, supra note 51; Leo Strine, Remarks at the Roundtable Discussions Regarding the Federal Proxy Rules and State Corporation Law 34 (May 7, 2007), available at www.sec.gov/spotlight/proxyprocess/proxy-transcript050707.pdf; see also William T. Allen, Jack B. Jacobs \& Leo E. Strine, Jr., The Great Takeover Debate: A Meditation on Bridging the Conceptual Divide, 69 U. CHI. L. REV. 1067, 1097 (2002) (proposing that every three years, stockholders should have access to proxy machinery on same terms as management). 


\section{A. To Clarify Delaware's Corporate Law}

The permitted range for Delaware corporate bylaws became muddied in the half-dozen years before the legislature passed $\S 112$. Delaware corporate lawyers were opining that shareholder authority in Delaware to push for election-controlling bylaws was limited. ${ }^{54}$ One major 2008 Delaware Supreme Court opinion, Computer Associates, controversially indicated that some bylaw provisions, such as these voting provisions, must always be subject to the board's fiduciary duty to consider what was best for the company at the time, forestalling boards from fully being bound in advance. ${ }^{55}$

Hence, a simple view is that some Delaware leaders wanted the 2009 law to affirm its standard enabling approach, albeit one that started with the default power in the hands of the incumbent board, as is usually the case for Delaware corporate law. Prior to the rise of the shareholder access controversy, many would have thought that even without a specific Delaware statute in place, Delaware law would permit bylaws governing election rules. In those terms, the 2009 legislation brought Delaware back to its normal enabling structure. ${ }^{56}$

But even in these mild terms, a federal-state interaction dominates stateto-state interaction. It was the SEC that first put shareholder voting on the corporate lawmaking agenda. It put it onto the Delaware Supreme Court's 2008 agenda via certified questions and persistent SEC activity on shareholder acc ess. Then Delaware authorities in 2009 codified Computer Associates' basics

\footnotetext{
${ }^{54}$ See McDonnell, supra note 26.

${ }^{55}$ Computer Associates, 953 A.2d at 238. That thinking has been criticized. See D. Gordon Smith et al., Private Ordering with Shareholder Bylaws, 80 FORDHAM L. REV. 125, 148-53 (2011).

When prodded by SEC certified questions on proxy access, the Delaware Supreme Court affirmed the state's long-held, board-focused, enabling view (and suppressed Delaware lawyers' views that shareholders could not make access bylaws). Then, the court oddly indicated that the bylaw could not confine board fiduciary discretion. The court's view was odd because every contract confines future fiduciary discretion, but deploys that discretion when the board agrees to that contract.

The analog is corporate board's fiduciary duty to shop its company when it agrees to a merger. But the merger setting differs sharply from the access setting, because boards and managers can readily be conflicted in the sale by the terms of the sale and how well they do in the sale; the duty to shop reduces the impact of their conflicts.

${ }^{56}$ Although the 2009 law could be seen as codifying Computer Associates and perhaps restricting the fiduciary out, the 2009 law did not specifically refer to Computer Associates, did not state that the court's holding was no longer good law, nor explicitly indicate that shareholders could control the vote on access, one wonders whether the drafters simply wanted to cut back Computer Associates. See Brett H. McDonnell, Setting Optimal Rules for Shareholder Proxy Access, 42 ARIZ. ST. L.J. 67, 103 (2011); Sabrina Ursaner, Keeping "Fiduciary Outs" Out of Shareholder-Proposed Bylaws: An Analysis of CA, Inc. v. AFSCME, 6 NYU J. L. \& BUS. 479, 494 (2010).
} 
and, pulling back on the access-barring tendencies of its courts and its lawyers. Even if we interpret the state's lawmaking as clarifying, traditional and not strategic, the clarifications appear to have been primarily prodded by federal, not sister state, action.

\section{B. To Be Relevant}

Commentators noted during the past decade that Delaware was losing relevance in key dimensions of corporate lawmaking. Securities law academics saw the state's core corporate legal structure-fiduciary duties and their interpretation-moving into federal courts, pendant to securities law claims. ${ }^{57}$ Delaware was not the preferred venue for merger litigation and, worse, firms were exiting from the Delaware judicial venue even when it was the most natural locus for the lawsuit. ${ }^{58}$

Said a prominent corporate lawyer about Delaware's access statute: "There is speculation that Delaware adopted this amendment to maintain its importance as the pre-eminent state for company incorporation and corporate law." 59 Delaware lawyers prefer to be involved in drafting tailor-made access bylaws and their leaders are prominent in the Delaware Corporate Law Council, which advises the Delaware legislature on corporate law matters.

In a more positive spirit, if shareholder access was coming anyway, public-spirited Delaware leaders could think that they would implement it better than the SEC. The Delaware Bar Association's comments to the SEC are in that

${ }^{57}$ Thompson and Sale saw this early by examining cases. Armour, Black, and Cheffins so conclude later, by inspecting dockets. See Robert B. Thompson \& Hillary A. Sale, Securities Fraud as Corporate Governance: Reflections upon Federalism, 56 VAND. L. REV. 859, 860-6 (2003); John Armour, Bernard Black \& Brian Cheffins, Is Delaware Losing its Cases? (2010), available at $\mathrm{http}: / / \mathrm{ssrn} . \mathrm{com} / \mathrm{abstract}=1578404$. The latter shows corporate lawsuits not just going federal, but also moving to other states' courts.

${ }^{58}$ See Theodore Eisenberg \& Geoffrey P. Miller, Ex Ante Choices of Law and Forum: An Empirical Analysis of Corporate Merger Agreements, 59 VAND. L. REV. 1975 (2006); Matthew D. Cain \& Steven M. Davidoff, Delaware's Competitive Reach, J. EMPIRICAL LEGAL STUDIES (forthcoming 2011) (manuscript at 28) (stating that firms exit Delaware forum, but fewer than in 2002); John Coates, Managing Disputes Through Contract: Evidence from M\&A (Aug. 14, 2011), available at http://ssrn.com/abstract=1915135.

${ }^{59}$ Charles M. Nathan, Delaware Law Changes to Facilitate Voluntary Adoption of Proxy Access, HLS FORUM (July 7, 2009), http://blogs.law.harvard.edu/corpgov/2009/07/07/delawarelaw-changes-to-facilitate-voluntary-adoption-of-proxy-access/; cf. Robert A. Thompson, Corporate Federalism in the Administrative State: The SEC's Discretion to Move the Line Between the State and Federal Realms of Corporate Governance, 82 NOTRE DAME L. REV. 1143, 1144 (arguing that state, that is, Delaware, law was largely unchanged after Enron and WorldCom scandals of 2002). 
positive spirit. ${ }^{60}$ Delaware players are proud of their state's corporate law mechanisms and see their work as superior to Washington's. ${ }^{61}$

\section{To Craft a Compromise}

The Delaware law has an aura of compromise. Access could be obtained, but not the open-ended, largely mandatory, one-size-fits-all access of the SEC's Rule 14a-11 proposal. (That rule, which the D.C. Circuit subsequently struck down, would have mandated that all public firms have shareholder access; neither corporations, nor their boards, nor their shareholders could opt out. Its mandatory nature had a contradictory, circular quality, as Joseph Grundfest has pointed out: it would have assured shareholder sovereignty in electing directors, but denied them sovereignty in deciding the election rules, barring shareholders from choosing, say, to bar small shareholders from nominating directors at company expense. ${ }^{62}$ )

Delaware thus could have been responding to the increasing power of its institutional investor constituency by formally providing shareholders with some access immediately, and with the necessary bylaw access switch to be turned on later at a propitious moment. And, if federal authorities' enthusiasm for access ended (because of a change of some minds at the SEC or because future elections brought about a change in the Commission's composition), then the state would control how access would be modulated in the future.

\footnotetext{
${ }^{60}$ Delaware Letter, supra note 50; see SEC Proxy Access Proposal Criticized by Delaware Bar, CORP. COUNSEL WEEKLY (BNA), July 29, 2009; cf. Strine, supra note 51.

${ }^{61}$ Cf. Leo E. Strine, The Delaware Way: How We Do Corporate Law and Some of the New Challenges We (and Europe) Face, 30 DEL. J. CORP. L. 673 (2005) ("the potential threat to economic efficiency that might result if the federal government further expands its role in corporate governance"); E. Norman Veasey, Musings on the Dynamics of Corporate Governance Issues, Director Liability Concerns, Corporate Control Transactions, Ethics and Federalism, 152 U. PA. L. REV. 1007, 1017-18 (2003) (although "Sarbanes-Oxley trumps [aspects of] state internal affairs law," the state should not despair, but "[r]ather . . . should inspire [it] to be a part of the solution.").

${ }^{62}$ See Grundfest, supra note 36 . If the reader needs to know my view on the merits, here they are: Access via the Rule $14 \mathrm{a}-8$ mechanisms that allow shareholders to cheaply set the bylaws is the place to begin. A default rule such as in $\S \S 112 \& 113$, without more, is unwise in giving too much authority to the incumbent board; Delaware ought to have incorporated a 14a-8-type rule into its legislation, to make it easier for shareholders to get the relevant bylaws. But barring shareholders from contracting away from shareholder access, as the SEC's Rule 14a-11 would, is also unwise. The law could, and should, start from a default different from no-access at all, say via access for a $10 \%$ coalition, but shareholders should be able to tie their hands if it seems wise to them to give their board more discretion.
} 


\section{To Facilitate the Business Roundtable's SEC Challenge}

Less charitable, almost Machiavellian interpretations of the statute's impact are possible.

When Delaware passed $\S 112$, a court challenge to SEC-promulgated access was as likely as such things can be before they happen. ${ }^{63}$ Mary Schapiro, the SEC chair, said she expected a lawsuit. "The U.S. Chamber of Commerce . . . wrote to Schapiro . . . saying it does not believe the SEC has the power to expand shareholders' ability to nominate directors. Oversight of director elections has been under the purview of state law since the nineteenth century and should stay that way, the group said." $" 64$

Said Gibson Dunn partner John Olson in the summer before the SEC acted: "If the commission ultimately adopts a mandatory federal access scheme, attempting to preempt state law in the area, a lawsuit is a certainty . . .., ${ }^{, 65} \mathrm{An}$ American Bar Association securities law task force of securities bar leaders put forward reasons why they thought the SEC lacked authority to issue access rules. ${ }^{66}$ In an earlier era, the SEC promulgated rules barring dual class common stock; the Business Roundtable challenged the SEC's authority to do so and won in the D.C. Circuit. ${ }^{67}$ Expectations were that the same kind of challenge to an SEC access rule would arise, and corporate groups said as much.

${ }^{63}$ See Tina Chi, SEC Likely to Grant Shareholder Proxy Access, but New Rules May Be Challenged, CORP. COUNS. WEEKLY (BNA), May 20, 2009; Yin Wilczek, SEC Delays Vote on Proxy Access Proposal, CORP. COUNSEl WeEKLY (BNA), Oct. 7, 2009 (predicting "well-funded challenge by business groups . . . [f]or example, the Business Roundtable"); CORP. COUNS. WEEKLY (BNA), Aug. 5, 2009, at 236; CORP COUNS. WEEKLY (BNA), July 15, 2009, at 211; Joann S. Lublin \& Kara Scannell, Provision in Bill Lets SEC Offer Investors More Boardroom Clout, WALL ST. J., June 28, 2010, at A4 ("The U.S. Chamber of Commerce, the nation's largest business lobby, had threatened to sue the agency, arguing it lacks authority to regulate proxy access."); ABA Task Force, supra note 25; Stephen M. Bainbridge, The Scope of the SEC's Authority Over Shareholder Voting Rights, 8 ENGAGE 25 (2007); Lipton \& Rosenblum, supra note 11; cf. Grundfest, supra note 33 (stating that it is difficult to reconcile most SEC proposals with the Administrative Procedure Act's admonition against an agency being arbitrary and capricious).

${ }^{64}$ Martha Graybow, Schapiro Braces for Fight over Proxy Access, REUTERS, Apr. 29, 2009, available at http://www.reuters.com/assets/print?aid=USTRE53S6I520090429.

${ }^{65}$ SEC Proposes New Proxy Access Rule, 24 CORP. COUNS. WEEKLY (BNA) at 161 (June 3, 2009) (emphasis added).

${ }^{66}$ ABA Task Force, supra note 28; cf. Letter from Henry A. McKinnell, Chairman, The Bus. Roundtable, to Jonathan G. Katz, Sec'y, SEC, (Dec. 22, 2003), available at www.sec.gov/rules/proposed/s71903/s71903-381.pdf (telling the SEC that it lacks authority to promulgate an access rule).

${ }^{67}$ Bus. Roundtable v. SEC, 905 F.2d 406 (D.C. Cir. 1990). The SEC in time induced the stock exchanges to bar listing of dual class common stock issues, thereby indirectly achieving its substantive goal. 
Doubts about SEC authority were deep enough to put that authority onto the congressional financial reform agenda during the 2008-2009 financial crisis, despite that shareholder access had little to do directly with the financial crisis. Congress formally authorized the SEC to promulgate an access rule in the 2010 Dodd-Frank financial overhaul. ${ }^{68}$

And even after Congress explicitly authorized the SEC to promulgate access to allay doubts about SEC authority, the Business Roundtable and the Chamber of Commerce challenged the SEC's August 2010 rule on analogous grounds ${ }^{69}$ - arguing that the SEC was arbitrary and capricious in ignoring state access rules. ${ }^{70}$ They urged first the SEC and then the D.C. Circuit to have "[d]eference to . . state law, such as Delaware Code Section $112 \ldots .,{ }^{, 71}$ The state of Delaware, through the state's solicitor, filed an amicus brief supporting the Roundtable and arguing that the SEC's Rule 14a-11 "would fundamentally alter the policy of stockholder choice embodied in [the 2009 Delaware law, in] Section 112." "T2 "SEC Rule 14a-11 . . f flouts an important decision recently made by the Delaware legislature and signed into law by Delaware's Governor." ${ }^{, 73}$ The Delaware solicitor urged on the D.C. Circuit the view that the SEC's access rules ran roughshod over the state's newly enacted $\S 112$. Federalism demanded that the court bar the SEC from doing so, the state solicitor said.

Consider, with the Delaware solicitor's brief in mind, the preemption atmospherics first and formal doctrine later. Federal judicial atmospherics differ if states have or do not have rules on shareholder access. The actual, ongoing, real existence of a Delaware access rule makes regulatory preemption and federal-state comity issues both real and vivid, in contrast to the theoretical, abstract bases if there were no major state statutory pronouncements on access.

${ }^{68}$ Dodd-Frank Wall Street Reform and Consumer Protection Act, Pub. L. No. 111-203, 124 Stat. $1376(2010)$.

${ }^{69}$ Brief in Support of Motion for Stay of Proxy Access Rules by Business Roundtable and Chamber of Commerce of U.S.,(Sept. 29, 2010).

${ }^{70}$ Order Granting Stay on Shareholder Director Nominations Rules, Exchange Act Release No. 63,031 (Oct. 4, 2010).

${ }^{71}$ Opening Brief of Petitioners Bus. Roundtable and Chamber of Commerce, supra note 44 , at 22 .

${ }^{72}$ Brief of the State of Delaware as Amicus Curiae in Support of Petitioners at 7, Bus. Roundtable and Chamber of Commerce v. SEC, 647 F.3d 1144 (D.C. Cir. 2011) (No. 10-1305), 2011 WL 2014797.

${ }^{73}$ Id. at 9. 
It would have been easier for the D.C. Circuit Court of Appeals to allow the SEC to act freely if no state had such a statute. Before Congress explicitly authorized the SEC to act on access, it would have been easier for the court to interpret that the SEC had authority if states were silent and the SEC was entering an empty room. It would similarly have been easier to ignore an arbitrary and capricious attack, along the lines that the SEC failed to adequately consider how its rule interacted with state law, if no such state law existed. But under Delaware law, in the absence of an authorizing bylaw, shareholders cannot get access. Federal authorities were countermanding that state rule by mandating shareholder power via the SEC's Rule 14a-11.

The Business Roundtable's brief appealed to such views. The simple atmospherics of its table of attachments makes its own implicit argument: on a single page, it lists the SEC regulation, the relevant federal statutes, and the Delaware statute. ${ }^{74}$ That's what counts for such lawmaking: Congress, the SEC, and Delaware corporate law. And the brief itself transforms the original, SEC lack-of-authority attack in an area traditionally committed to state lawmaking into a parallel arbitrary and capricious one:

The [SEC's] adopting release is arbitrary and capricious in its treatment of state law. The rules' stated purpose is to effectuate shareholders' "state law rights" to nominate directors. ... . [But] Delaware, where more than half of U.S. public companies are incorporated ...., has a law that specifically addresses shareholder access to the proxy for director nominations and provides that an access mechanism may be established by a company's shareholders through a bylaw amendment .... While claiming to effectuate state law rights, the [SEC's] Proxy Access Rules effectively moot them. . . ${ }^{75}$

\section{E. To Quiet the Federal Authorities}

Consistent with the less charitable litigation-strategy possibilities, some corporate players could have wanted to reduce the odds that the SEC would act

\footnotetext{
45 , at 64 .

${ }^{74}$ Opening Brief of Petitioners Bus. Roundtable and Chamber of Commerce, supra note

${ }^{75}$ Brief of Bus. Roundtable, supra note 69, at 7 (emphasis added). Joseph Grundfest had likewise argued that Delaware access law eviscerates the SEC's own view that the SEC, via Rule 14a-11, would be replicating the state-based annual meeting, but through the proxy solicitation process. Delaware's more limited access rules define the state-based process, he shows, and hence the SEC is going further than creating a proxy-oriented state-based meeting. See Grundfest, supra note 36 .

These powerful arguments were pressed on the D.C. Circuit, which did vacate the SEC's most aggressive voting rule, $14 \mathrm{a}-11$, but its articulated rationale for doing so was more prosaic - $\mathrm{a}$ failure to adequately do a congressionally-required cost-benefit analysis.
} 
in the end. Some corporate players may have wanted Delaware to pass a rule in 2009 that had limited impact, because even a limited Delaware rule could slake Washington's appetite for strong access, by affecting Congress, the SEC, or the courts. After the 2008 election, those corporate players that were influential in Delaware, like the corporate bar, may have assessed that the likelihood of SEC action was high and, in the context of the 2008-2009 financial crisis, would be widely supported in the new Congress.

At the time Delaware acted in 2009, Congress was considering lifting any doubt about the SEC's authority to promulgate access by passing an explicit statute $^{76}$ and eventually it did so. Delaware officials understood the potential consequence: The Dodd-Frank bill's corporate governance provisions, like Sarbanes-Oxley's earlier federal inroads into corporate lawmaking, "some [Delaware] officials say[,] could . . . erode Delaware's corporate leadership role, and eventually the revenue the state gets from companies incorporating there."77 But if Delaware enacted access early in 2009, Congress might have been less willing to so authorize the SEC. Said one astute corporate lawyer: "the Delaware General Assembly may have thought that by enacting a specific proxy access bylaw before a federal proxy access law or rule was enacted, the federal legislators and regulators would find it, legally and politically, more difficult to supersede the new Delaware law." ${ }^{, 78}$ I understand that in the run-up to DoddFrank, at least one Delaware corporate leader argued to Congressman Frank that no congressional action was needed on access because Delaware's $\S 112$ does all that's needed. ${ }^{79}$

The Delaware statute could have satisfied a busy Congress that the states were "on it," enabling Congress to focus its financial reform attention elsewhere. And Congress, with budgetary control of the SEC, can influence

\footnotetext{
${ }^{76}$ Senator Schumer proposed such a statute and a provision is in the eventually-enacted omnibus financial reform bill. The 2009 Shareholder Bill of Rights Act, S. 1074, 111th Cong. (2009).

${ }^{77}$ Nicole Gaudiano, State's Corporate Dominance Threatened by Senate Bill, Some Fear, GANnEtT News SERviCE, May 18, 2010 (“'I don't think it happens overnight,' said [Charles] Elson, a University of Delaware professor. 'It's just the beginning of a slow, steady erosion of our influence and revenues.' . . 'Delaware Secretary of State Jeffrey Bullock said federal 'intrusions' ... could dilute the effectiveness of Delaware law.").

${ }^{78}$ Nathan, supra note 59 (emphasis added); cf. Memorandum from Wachtell, Lipton, Rosen \& Katz on Proxy Access Revisited (Mar. 29, 2010) (on file with author).

[T] he best way to conduct an experiment of the costs and benefits [of access] is not to usurp the traditional role of state corporate law ..., but rather to permit proxy access on a state-by-state, case-by-case, company-by-company basis.

${ }^{79}$ Personal communication from Charles Elson, November 11, 2011.
} 
where the SEC puts its efforts. ${ }^{80}$ A weak but plausible Delaware statute could have induced (and may still induce) Congress to realign the SEC's priorities. One can think of the moves in chess terms: director-friendly players sacrificed a pawn of explicit but weak state access for positional advantage on the chessboard in Washington where strong access was in play.

Said one SEC commissioner, who opposed the SEC access rules: "[S]tates are in the midst of promoting a tailored company-by-company approach to shareholder director nominations . . . . Consider . . . [Delaware's] new section $112 \ldots .{ }^{81}$ In a major law firm submission to the SEC, the law firms, in opposing full-scale, SEC-mandated access, argued that given Delaware's new shareholder voting statute, Washington action was unnecessary: "Indeed, Delaware expressly contemplates that proxy access provisions will be included in the by-laws [citing to Delaware, $\S 112] . .$. [The better approach is to] address[ the issue] at the company or state level, and in any event, not as part of the debate on [SEC-inspired] proxy access." 82

As one prominent corporate lawyer said when Delaware was on the verge of passing its access rule, Delaware will pass access and "[a]t that point, . . . there isn't much reason for the SEC to try to create a whole new proxy access scheme that would preempt state law when state law had already provided for access." 83 That savvy corporate inside players think in these terms-of shielding their favored state-based law and their boardroom constituents via moderate concessions to the Feds - is not to be disputed. A century of thinking on the race among states to make corporate law has states in general and Delaware in particular thought to regularly act strategically in keeping state coffers filled with franchise fee revenues. Chief Justice Myron Steele of the

${ }^{80}$ Cf. Arthur Levitt, Don't Gut the S.E.C., N.Y. TIMES, Aug. 8, 2011, at A17; Ronald D. Orol, Democrats, GOP spar over SEC, CFTC budgets, MARKETWATCH, Feb. 14, 2011, http://www.marketwatch.com/story/democrats-gop-spar-over-sec-cftc-budgets-2011-02-14; Tom Braithwaite, CFTC seeks to ease derivative concerns, FIN. TIMES, Feb. 15, 2011.

${ }^{81}$ Troy Paredes, Commissioner, SEC, The Proper Limits of Shareholder Proxy Access, Remarks at the Center for Capital Markets Competitiveness, U.S. Chamber of Commerce (June 23, 2009); cf. Memorandum from Wachtell, supra note 78 (state solutions are seen as superior to SEC action, even as Congress authorizes SEC action).

${ }^{82}$ Seven Law Firm Letter, supra note 11, at 14. One could imagine Delaware "talking" to Congress as well, in that individual members of Congress would not parse the statute as precisely the SEC chair had, to see that it appears to be wide but is narrow. More severely, Congress often defers to state lawmaking and, if economic and financial crisis atmospherics had differed, might even have pressed the SEC not to act on access, particularly if the states were already doing so. Interests that would want the SEC to withdraw could be expected to insist to Congress and the SEC that Delaware had acted - and they still might push this on the SEC or Congress. Analysis of the statute's weakness in actually providing access might never catch up with the pressure and announcement that the states are "on it."

${ }^{83}$ Wilczek, supra note 32, at 2. 
Delaware Supreme Court, when complaining about a "populist frenzy" in Congress on corporate issues, indicated that Delaware and its allies "concede proxy access as a way to blunt calls for shareholder say-on-pay." ${ }^{, 84}$

\section{F. Contractual Parallels?}

Parallel private efforts occurred. A law firm representing boards and senior managers had recognized earlier that boards could deflate the decade's pressure for shareholder access by acquiescing and adopting weak shareholder access bylaws. ${ }^{85}$ Their model access bylaw, however, was not substantively useful to shareholders wanting cost-effective access. Each shareholder could nominate only a single director, and only shareholders owning at least $5 \%$ of the company's stock could nominate a director-an ownership level uncommon in American public firm stockholding. Worse yet for the shareholder activist, the single nomination could not be made by shareholders aggregating their stock to a 5\% holding-a roadblock seriously impeding shareholders at the many companies that lack a single 5\% shareholder, and which are the very companies where the distance between shareholders is greatest. It's those diffusely-owned firms where managerial and board insulation is likely to be highest that could most benefit from shareholder access. Hence, companies could use the law firm's model bylaw to appear to facilitate access, but without facilitating meaningful shareholder access. The strategic intent is clear, as the drafting law firm said that its purpose was to recommend "the preemptive adoption of a reasonable and ... tailored bylaw, in part to deter, or discourage adoption of, more extreme ... shareholder access ...., ${ }^{86}$

Delaware's access statute, whose barriers to meaningful access are substantial but lower than the law firm's model managerial bylaw is, in its effect (regardless of the legislators' intent) in the same spirit. It has the aura of access, but given the "Catch-22" effect of no cheap access to the proxy statement without shareholders first succeeding in a not-so-cheap proxy fight, it does little to reallocate authority between boards and shareholders.

\footnotetext{
${ }^{84}$ Marcus, supra note 48, at 1 (quotation is from the reporter, not the chief justice) (the justice left unclear in the simple quotation whether the concession should be via Delaware formal law or simply by not opposing federal action).

${ }^{85}$ Memorandum from Wachtell, Lipton, Rosen \& Katz on Model Proxy Access Bd. Resolution and By-Law (May 7, 2009), available at http://www.wlrk.com/webdocs/wlrknew/ WLRKMemos/WLRK/WLRK.16648.09.pdf. See Bebchuk \& Hirst, supra note 24.

${ }^{86}$ Mirvis, supra note 47 , at 1 .
} 


\section{The Political Economy Abstractions}

These Delaware-Washington differences on shareholder voting are inconsistent with the classic view of corporate law emerging from a state-tostate competitive cauldron. These differences also induce us to do more than to reconceptualize the jurisdictional divide as more vertical than horizontal as they demand a big picture, political economy reconceptualization of American corporate lawmaking: two jurisdictions make American corporate law and each has differing private inputs, differing aggregation mechanisms for decisionmaking, differing philosophies, and differing public policy goals. Not only can Washington influence Delaware, but Delaware can position itself to influence, or its position can be used by savvy players, to influence federal outcomes. The vertical "race" is two-way.

Delaware, we know, gets a hefty fraction of its state budget from corporate franchise fees and related charges. The immediate players who bestow these benefits on Delaware are corporate boards and shareholders, each of which has to approve reincorporation into Delaware for a non-Delaware company to become a Delaware company paying franchise fees to the state. The direct political salience of other interests (such as corporate employees, citizens affected by corporate behavior, and public policymakers looking at how best to organize the economy) is not vivid in influencing Delaware lawmakers. Those other interests neither vote in Delaware elections nor do they directly provide franchise fees. The absence in Delaware of a constituency statute (common in other states, formally allowing the board to take into account non-shareholder interests in decisionmaking, particularly in merger decisions) symbolizes the narrow scope of influential interests in Delaware - its boards and shareholders that count, with the typical statutory mechanisms being enabling for the two groups, not mandatory. ${ }^{87}$ Delaware's philosophy is that corporate law ought to be enabling, with decisionmaking authority generally resting in the first instance in the boardroom. ${ }^{88}$

\footnotetext{
${ }^{87}$ And corporate lawyers like tailor-made deals, which require more legal skill. Corporate dealmaking lawyers are influential in Delaware, typically drafting the legislation; they are less influential in Washington.

${ }^{88}$ From where it typically does not migrate. See Hansmann, supra note 40, at 11.
} 


\section{A. Interests in Washington}

Washington's political inputs are broader than Delaware's. On the publicspirited plane, SEC officials have a vision of how the American economy would be run best; some at the SEC see a need for greater managerial accountability, many are oriented more toward capital markets efficiency than toward Delaware's philosophy of boardroom autonomy. And general American popular opinion is often anti-corporate and that anti-corporate opinion counts more in Washington than in Delaware. On the interest group plane, labor and political shareholder activists - state pension funds are often politically-influenced and the AFL-CIO and other labor shareholder funds, although small, are activehave more weight in Washington, particularly for congressional Democrats or during a Democratic administration.

The interest-group view would see shareholder access, particularly as embodied in the SEC's Rule 14a-11, as primarily benefiting these constituencies. ${ }^{89}$ Even a charitable view of the SEC's political economy in this dimension - one combining the public-spirited without ignoring the relevant interest groups - is largely consistent: Corporate governance reformers want to make managers more accountable. They may indeed see agenda-driven activists, such as CalPERS and other state pension funds, as having pernicious and costly side-agendas, but see these costs as more than offset if access improves the accountability of managers and boards. Or, less charitably, they may simply be captured by these Washington-savvy interests.

In this interest-group-oriented view, we get corporate governance rules at the federal level that tilt toward public-pension-based shareholder activists with a nonfinancial agenda, while we get corporate rules at the state level that tilt toward corporate insiders. Each level is distorted from the overall public interest. In this pessimistic view, neither level is politically well-suited to produce the most economically efficient corporate law possible.

\footnotetext{
${ }^{89}$ See Grundfest, supra note 36. For example, 14a-11's 3-year holding period requirement would have been one that indexed public pension funds - influential now in Washington - could often meet, but one that activist hedge funds could not have. State pension funds with indexed, long-term portfolios would have fit the 3-year holding period rule nicely; hedge funds accumulating large block quickly would not. If the Delaware rhetoric suggests capture by, or at least the influence of, boards, 14a-11's structure was evocative of SEC capture by the public pension funds and their allies.
} 


\section{B. Interests in Delaware}

The contrasting inputs paint a political economy paradigm. Delaware satisfies its prime constituencies-directors and many shareholders-and doesn't work as hard to satisfy others, such as activist interests wanting the corporation to be more accommodating to social claims on the firm or publicspirited corporate policymakers seeking to minimize managerial agency costs for efficiency reasons. It could have better satisfied the latter by enabling shareholders to put into the company's proxy solicitation bylaw proposals that would define the terms of company-paid elections. It did not.

At the same time, Washington is either too busy to act or, when it does act, is overly motivated by political interests with electoral influence. Financial shareholders, with neither ties to management nor non-financial goals, have reason to find that Delaware and Washington each come up with rules that they, financial shareholders, find imperfect. The first tends to favor insider-boards, the other tends to favor activist shareholders with a noncorporate, and sometimes even an anti-corporate, agenda.

In this view, Delaware's corporate law council is where directors' representatives (via their lawyers) meet with some shareholders' representatives to draft corporate law that will be seen as satisfactory enough to Washington actors in Congress, the federal agencies, and the federal courts, so that those national actors leave the Delaware result alone. Or it can be seen as the place where directors and their lawyers make a counteroffer to the SEC and the activist, public pension fund shareholders.

One can abstract this Washington-Delaware political economy contrast even further. Posit that the public firm consists of three players: managers, activist public pension fund shareholders, and financial shareholders. Of these three, financial shareholders are the swing group. They could ally with activist shareholders to reduce managerial drift. Or they could ally with managers to suppress the quasi-political voices of the most likely activists.

The rhetoric of shareholder access has more than a little of this kind of Roundtable and the Chamber of Commerce appeal to financial shareholders to (implicitly) tolerate some managerial drift in exchange for shutting out other interests - pushed by public pension funds and labor-oriented shareholdersthat would be less likely to maximize shareholder profits. The Delaware arena, which unlike Washington allows no direct representative input for these other interests, is then put forward by managers and their organizations, such as the 
Business Roundtable and the Chamber of Commerce, as the better arena not just for managers and boards, but also for financial shareholders.

In this view, Delaware made a bid to control proxy access rules, via $\S \S 112$ and 113. It tilted authority toward incumbent boards. At first Washington rejected its bid, as the SEC promulgated its own access rules anyway. But then the D.C. Circuit, in the Business Roundtable lawsuit, struck down Rule 14a-11. Delaware and its interests, in this strategic view, mostly got its way. ${ }^{90}$

\section{Political Economy Contrasts}

The political economy contrast in the 2002-2003 SEC access debate maps onto the Washington-Delaware differences. Proponents of shareholder access wanted it to reduce managerial agency costs. With ownership in large American firms diffuse, and with shareholder power weak, access could raise shareholders' voice in the boardroom and lower board and managerial drift from shareholder value. It arguably could, better than the status quo, cabin managerial self-interest in their own compensation and accountability.

But critics of access put forward the downside that special interest shareholders would be the primary activists, who would push firms to a corporate agenda that favored their, or their allies', interests, with that push likely to often be at odds with financial shareholders' goals. As two opponents of access stated in a prominent attack, access would yield an "influx of special interest directors," would raise "the risk of balkanized and dysfunctional boards," and raised

serious doubt as to whether institutional shareholders, public pension funds, and labor unions - the parties most likely to qualify for the right to include director nominees in a company's proxy statement under most proposals - are well-suited to the role of nominating directors. Each has duties to its own constituencies; each has its own agenda ... ${ }^{91}$

90 The SEC had self-stayed Rule $14 \mathrm{a}-8$ as well when the $14 \mathrm{a}-11$ litigation was filed. Elements in the corporate bar argue that the SEC should not, because the DC Circuit opinion made validity of $14 \mathrm{a}-8$ in its present form questionable. See Stanley Keller, What Now for Proxy Access?, HLS FORUM (Aug. 17, 2011), http://blogs.law.harvard.edu/corpgov/2011/08/18/whatnow-for-proxy-access. It eventually lifted its self-stay on the amended Rule 14a-8.

${ }^{91}$ Lipton \& Rosenblum, supra note 11, at 67 (emphasis added). 


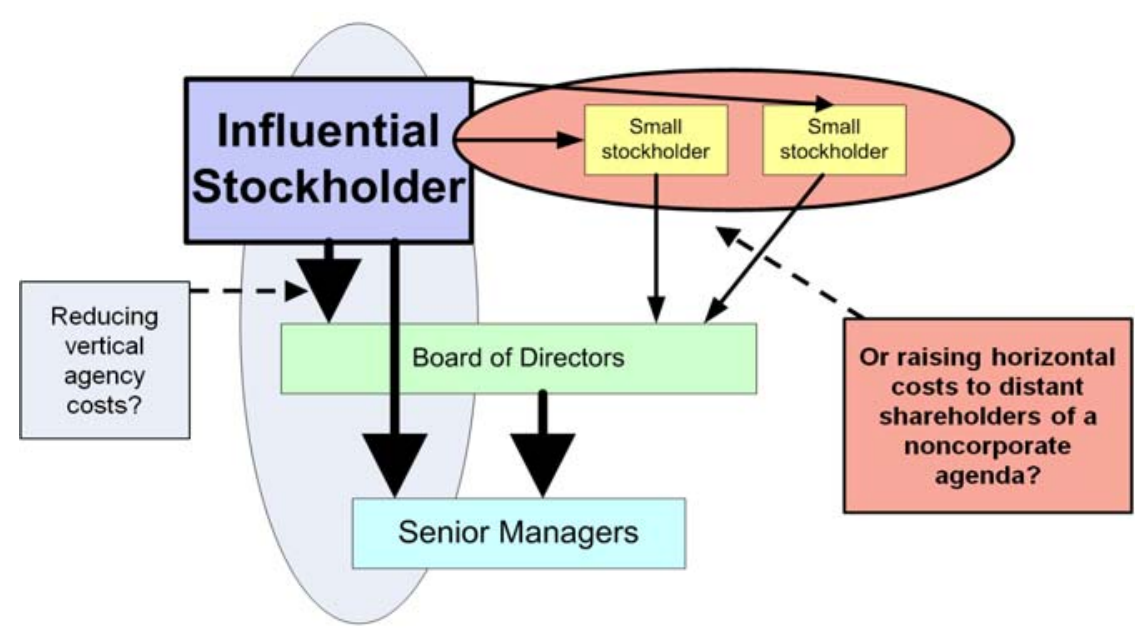

Figure 1. Activism of the influential shareholder: Reducing vertical agency costs vs. raising horizontal influence costs

Think of the interest group split in this way: Activist shareholders sought a rule that would reduce managerial agency costs, focusing on the vertical problem of the large public firm, illustrated in Figure 1. But opponents of access instead saw the analytic in terms of influential activist shareholders, such as public pension funds, obtaining benefits for themselves and their allies (such as politicized interests, labor-oriented players, and social policy groups), not for all shareholders generally, also illustrated in Figure 1. ${ }^{92}$

\footnotetext{
${ }^{92}$ Consider the statements of two SEC commissioners. Said Commissioner Casey: I believe many [investor] activists will concede that their interests in proxy access do not lie solely in the ability to successfully place a nominee on a company's board of directors; instead, the proxy access right is also an important means of obtaining leverage to seek outcomes outside of the boardroom that may otherwise not be achievable - outcomes that are often unrelated to shareholder value maximization.
}

Kathleen L. Casey, Comm'r, SEC, Statement at Open Meeting to Adopt Amendments Regarding Facilitating Shareholder Director Nominations (Aug. 25, 2010), available at http://www.sec.gov/news/speech/2010/spch082510klc.htm (emphasis added). Former SEC Commissioner Paul Atkins likewise argued that:

It's no coincidence that only unions and cause-driven, minority shareholders want this coveted access. They would use it to advance their own labor, social and environmental agendas instead of the corporation's goal of maximizing long-term shareholder wealth. The rule will give them pressure points with which to hold companies hostage until their pet issues are addressed. 
Caught in the middle were financial shareholders (think: mutual funds and their beneficiaries, hedge funds, individual owners) who wanted better corporate management but could not capture any of the expected special influence benefits. Figure 2 illustrates their dilemma. They wanted greater managerial accountability, but not enhanced influence for other shareholders that would enable their capturing side benefits, benefits that would not be shared with the financial shareholders.

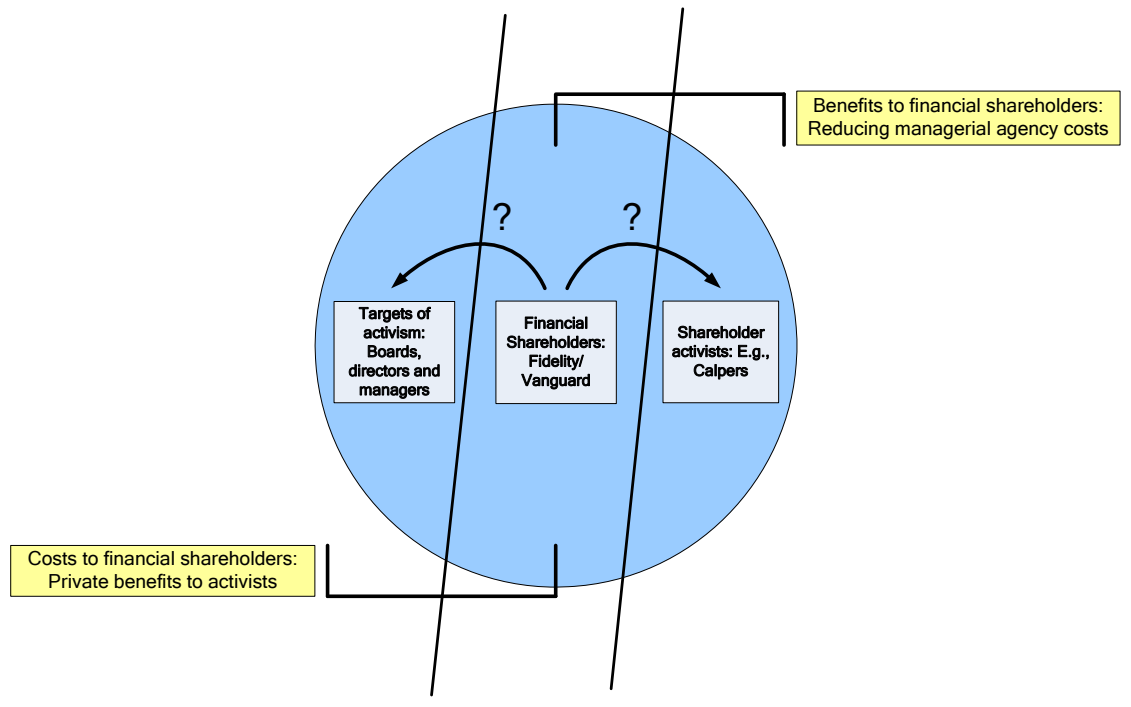

Figure 2. Costs and coalitions: The financial shareholder as swing player in access

The managerial anti-access rhetoric could be seen as an effort to turn financial shareholders (i.e., those who weren't politicized state pension funds or labor-oriented funds) against access. The message from the managerial quarter was, when translated: yes, you financial shareholders will lose some value because of managerial agency costs if there's no shareholder access, but you would lose as much or more value from enhanced shareholder influence of the "wrong" kind, i.e., influence that is not for shareholders' general benefit. ${ }^{93}$

Unions and special-interest groups successfully lobbied Congress to include a provision in the recent Dodd-Frank Act to empower the SEC to make rules regarding proxy access.

Paul Atkins, The SEC's Sop to Unions, WALL St. J., Aug. 27, 2010, at A15. The special interests he identified are "politically powerful trade-union activists, self-nominated shareholder-rights advocates, [and] trial lawyers." Id.

93 Cf. E.E. Schattschneider, The Semisovereign People: A ReAlist's View OF DEMOCRACY IN AMERICA (1st ed. 1960) (political scientist maps how politicians seek to define the most salient issue in a way that breaks or makes coalitions, to the politician's electoral benefit). 
Figure 2 illustrates this appeal to financial shareholders, as an effort to peel off an influential interest group from supporting access.

The official submissions made to the SEC during its rulemaking period break along parallel lines. The staff summarized the 500 comments into the groups that favored, that opposed, and that had mixed views on the SEC's 2003 shareholder access proposal:

A significant majority of the commentators, comprising virtually all of the unions; pension funds; social, environmental, and religious funds; a majority of institutional investors and institutional investor associations; a majority of investment advisers and managers; and a majority of individuals, supported the proposed rules. The exceptions were corporations, corporate executives, and corporate directors; law firms and attorneys; and most of the associations (primarily business associations), which were nearly unanimous in their opposition to the proposed rules. ${ }^{94}$

That is, the special-interest activists were all for the SEC rule, and boards and their lawyers were all against it. But financial investors were split, with a majority in favor of enhancing shareholder power via access. Figure 2 illustrates the opposing pulls on financial shareholders.

The opponents to the SEC's proxy access rules pushed the specialinterest argument hard, setting it forth not just in their SEC submissions but again in the litigation challenging the SEC rule, on the first page of their final brief to the D.C. Circuit Court of Appeals:

[T] he shareholders most likely to use the Rules are union and government pension funds. These funds, while not typically cited for sound financial management, have a history of using shareholder activism to pursue noninvestment-related objectives that depart from other shareholders' interests. ${ }^{95}$

94 SEC, Summary of Comments: In Response to the Commission's Proposed Rules Relating to Security Holder Nominations, Exchange Act Release No. 34-34626 (Mar. 5, 2004), available at $\mathrm{http}: / / \mathrm{www} . \mathrm{sec} . g o v /$ rules/extra/s71903summary.htm (overview section).

${ }^{95}$ Reply Brief for Petitioners Business Roundtable and Chamber of Commerce at 2, Bus. Roundtable and Chamber of Commerce of U.S. v. SEC, 647 F.3d 1144 (D.C. Cir., 2011), No. 101305; see Petitioner's Nov. 30, 2001 Brief at 2, 10-12, 40-42 (stating that the SEC failed to "mention union and government funds or their activism"); see also Marleen O'Connor, Labor's Role in the Shareholder Revolution, in WORKING CAPITAL: THE POWER OF LABOR'S PENSIONS 67, 71 (Archon Fung et al. eds., 2001) ("[S]pecial interest investors such as union and government pension funds ... would use access to obtain concessions from companies ... [even] where there was no serious intent that the candidate win"; touting the use of shareholder proposals to gain access to 'behind the scenes meetings with managers' in which "it is commonly understood ... that union may discuss labor issues as well .... If these negotiations proceed favorably the notion is that the union will withdraw its shareholder proposals."). 
A major corporate cause célèbre in 2003 and 2004 made these managerial conceptual negatives vivid. Much attention from managers and the business media was given to CalPERS' involvement in a bitter union strike at Safeway, a large supermarket chain. CalPERS - the huge, at the time labor-influenced, California state pension fund-encouraged Safeway to settle the strike favorably for the strikers, with CalPERS using corporate governance weapons to push its view. ${ }^{96}$ The CalPERS-Safeway incident became prominent among managers and their media allies as a cautionary tale on the perils of easy access to the company's director election proxy statement for public pension funds. ${ }^{97}$

\section{$* * *$}

We could interpret the Delaware action as one in which the state enacts shareholder voting that is weaker than the SEC rule and weaker than the preferences of the interest groups, such as public pension funds, that are influential with the SEC. A nimble Delaware sees the shift in congressional and SEC preferences after the 2008 election and puts a rule in place that gives enough of what the relevant federal players want so that, the nimble actors expect, the federal authorities will refrain from seeking more and will instead turn their attention elsewhere. Political scientists have used spatial models of Supreme Court behavior similarly. The Court, say some analysts, positions itself at times away from its true preferences and between its true preferences and its perception of congressional preferences. It strategically picks its position

${ }^{96}$ See Grundfest, supra note36; Canned at Calpers, WALL ST. J., Dec. 2, 2004, at A12; Tony Jackson, Overpaid Chief Executives under Fire at Davos, FIN. TIMES, Jan. 29, 2007 ("Of those institutions seeking votes on executive pay, . . quite a few were US state and public-sector pension funds: a group which, shall we say, [has] a wider social agenda than the average CEO would like."); Randall S. Thomas \& Kenneth J. Martin, Should Labor Be Allowed to Make Shareholder Proposals?, 73 WASH. L. REV. 41, 61 (1998) (unions use 14a-8 during labor disputes); cf. Petitioner's Brief, supra note 64, at 12 (bringing Safeway-type actions forward as a cost of access). And, the finance media did not forget Safeway when the D.C. Circuit struck down the most aggressive part of the S.E.C.'s 2010 access rules; see SEC Smackdown, WALL ST. J., July 25, 2011, at A12 ("[R]emember how the mammoth California pension fund Calpers browbeat grocer Safeway for union interests?").

${ }^{97}$ Jonathan Weil \& Joann S. Lublin, Gadfly Activism at Calpers Leads to Possible Ouster of President, WaLl ST. J., Dec. 1, 2004, at A1. The union activist pension president was later ousted. Canned at Calpers, supra note 97. For an example of the relevant activism, see the pension fund's Letter, dated Dec. 17, 2003, from CalPERS to the Chairman, President \& CEO of Safeway Inc., dated Dec. 17, 2003, re United Food and Commercial Workers Labor Negotiations ("[Y]our company is currently engaged in negotiations with the UFCW regarding issues, among others, over basic health benefits. We wish to express our deep concern regarding the status of these negotiations and we encourage you to resolve them fairly and expeditiously."). 
to reduce the chance of congressional action that would be even further from the Court's true preference. ${ }^{98}$

There's much evidence here of a Delaware-Washington strategic positioning that's parallel—one in which state-to-state competition for chartering revenues plays no role.

\section{CONCLUSION}

The lawmaking on the shareholder vote in the past decade fails to fit the classic analysis of state competition in making corporate law. The main action was in Washington, not the states. The major corporate state, Delaware, did act in the end, but not due to state competition. Either it came to its own view of the merits of eased shareholder voting rules or it was influenced by the Washington action. There's much evidence that the latter played a strong role.

Shareholder voting reform also has a political economy and federalism dimensions that may determine the shape of the outcome as much as, or more than, views of the merits. Shareholder access has been core for corporate activist reformers during the past decade. The early action was at the SEC, as the scandals of the early part of the decade allowed and induced reformers to put a broad access rule onto the SEC agenda. For most of the decade the Delaware players did nothing to advance shareholder access. When the state players acted, they impeded it.

Then, in 2009, Delaware unexpectedly passed an access statute. Surely some responsible Delaware corporate lawmakers and legislators became convinced by the ongoing Washington debate that access was a good idea whose time had come. But just as plausible is that the legislative result also reflected anti-access thinking from some, with the Delaware legislature passing what its board-centered corporate constituency saw to be a minimallyacceptable access rule that would slow down and maybe stymie federal shareholder access rules. Surely managerial players have pressed such views on the SEC and the federal courts.

98 See Mario Bergara, Barak Richman \& Pablo T. Spiller, Modeling Supreme Court Strategic Decision Making: The Congressional Constraint, 28 LEG. STUD. Q. 247, 248-9 (2003) (analyzing Supreme Court moves from its preferred position in order to slake Congress's appetite to act); see also Anna Harvey \& Barry Friedman, Ducking Trouble: Congressionally Induced Selection Bias in the Supreme Court's Agenda, 71 J. Politics 574, 574-6 (2009); William N. Eskridge, Overriding Supreme Court Statutory Interpretive Decisions, 101 YALE L.J. 331, 335 (1991); John Ferejohn \& Barry Weingast, A Positive Theory of Statutory Interpretation, 12 INT'L J.L. \& ECON. 263 (1992). 
The federal-state interaction on corporate lawmaking is thus not just that Washington makes corporate law on its own and not just that Washington's corporate lawmaking can influence Delaware's. It's also that Delaware can influence Washington outcomes, either strategically or by having that sort of impact. Despite that the Delaware rule would not give immediate meaningful access, it had the aura of real access, it enabled the rhetoric of shareholder choice as an alternative to the SEC rules, and that aura and those rhetorical moves could have been thought likely to slow down Washington from acting to implement full access. Delaware-Washington influence on corporate lawmaking is two-way. The D.C. Circuit did strike down the most wide-reaching of the SEC access rules.

It would be wrong to attribute a single, stained view to most Delaware players, especially one with such a strongly Machiavellian strain. But even public-spirited views will tend to be selected, emphasized, and highlighted when there are interests in the political environment that do better if such views become law. Those interested in the outcome will push public-spirited accounts in which they sincerely believe, to properly allocate power among shareholders and directors in the American corporation.

While Delaware has long been thought to have a self-interested eye on the cash register for franchise fees when it makes corporate law, this level of Machiavellian calculation is not needed to make out the strategic interaction story here. Concepts of cognitive capture have already moved from psychology to finance to help explain government decisionmaking during the recent financial crisis. ${ }^{99}$ Similar concepts can well apply to corporate players. Ideas emerge. The ideas can capture the imaginations of lawmakers and those who influence lawmakers. Sometimes those ideas also map onto the self-interest of those who promote the ideas, even if the ultimate public decisionmakers are free from that stain of self-interest.

${ }^{99}$ Cf. RAGHURAM G. RAJAN, FAULT LinES (2010). Consider his analytic of the relationship between Henry Paulson, the Secretary of Treasury at the beginning of the crisis, and the financial firm he previously led, Goldman Sachs, said to benefit from the Secretary's decisions:

I don't think for a moment that Paulson, for example, was doing this because he was benefiting Goldman Sachs. ... [O]ne of the things you learn when you read his book is the extent of [his] cognitive capture, the extent to which he doesn't seem to be worried about the picture of the secretary of the Treasury calling GE, in one case, or Goldman Sachs to ask for their opinions. But what does come out is a person who thinks he is doing the right thing by the United States.

... [T]hese people were doing their best, but in an environment where they were getting filtered information.

Interview by Joanne Myers with Raghuram Rajan, Carnegie Council (May 12, 2010), available at http://www.carnegiecouncil.org/resources/transcripts/0286.html/_res/id=sa_File1/Fault_Lines.pdf. 
Delaware and Washington interact in making American corporate law. Delaware cannot go further than Washington would allow in making corporate law. And sometimes it is pulled along in the undertow of a federal wave, either pulled to where it did not otherwise want to go or motivated to reposition itself in order to slow down that wave by moving along but not going as far as Washington would. That kind of conflict, positioning, and at times cooperation is core to the understanding of American corporate lawmaking.

Rather than thinking of corporate law as being made in a cauldron of state-to-state competition, as has been traditional for nearly a century, the thinking on jurisdictional pressure on corporate lawmaking needs to rotate from the state-to-state horizontal level to the federal-state vertical dimension. How the two polities interact defines a good part of the terrain for the politics of shareholder and managerial power in the large American corporation. ${ }^{100}$ The shareholder access statute in Delaware, when interpreted in light of the activity and pressure originating in Washington, well illustrates that concept of federalstate interaction as often being more important than state competition in understanding the shape of this part of state-made corporate law. It shows not only how Washington can influence Delaware, but also how Delaware can affect and potentially even determine the federal corporate lawmaking agenda. This federal-state, two-way interaction in corporate lawmaking was on vivid view in the past decade.

${ }^{100}$ Roe, Delaware's Competition, supra note 10; Mark J. Roe, Delaware's Politics, 118 HARV. L. REV. 2491 (2005). 